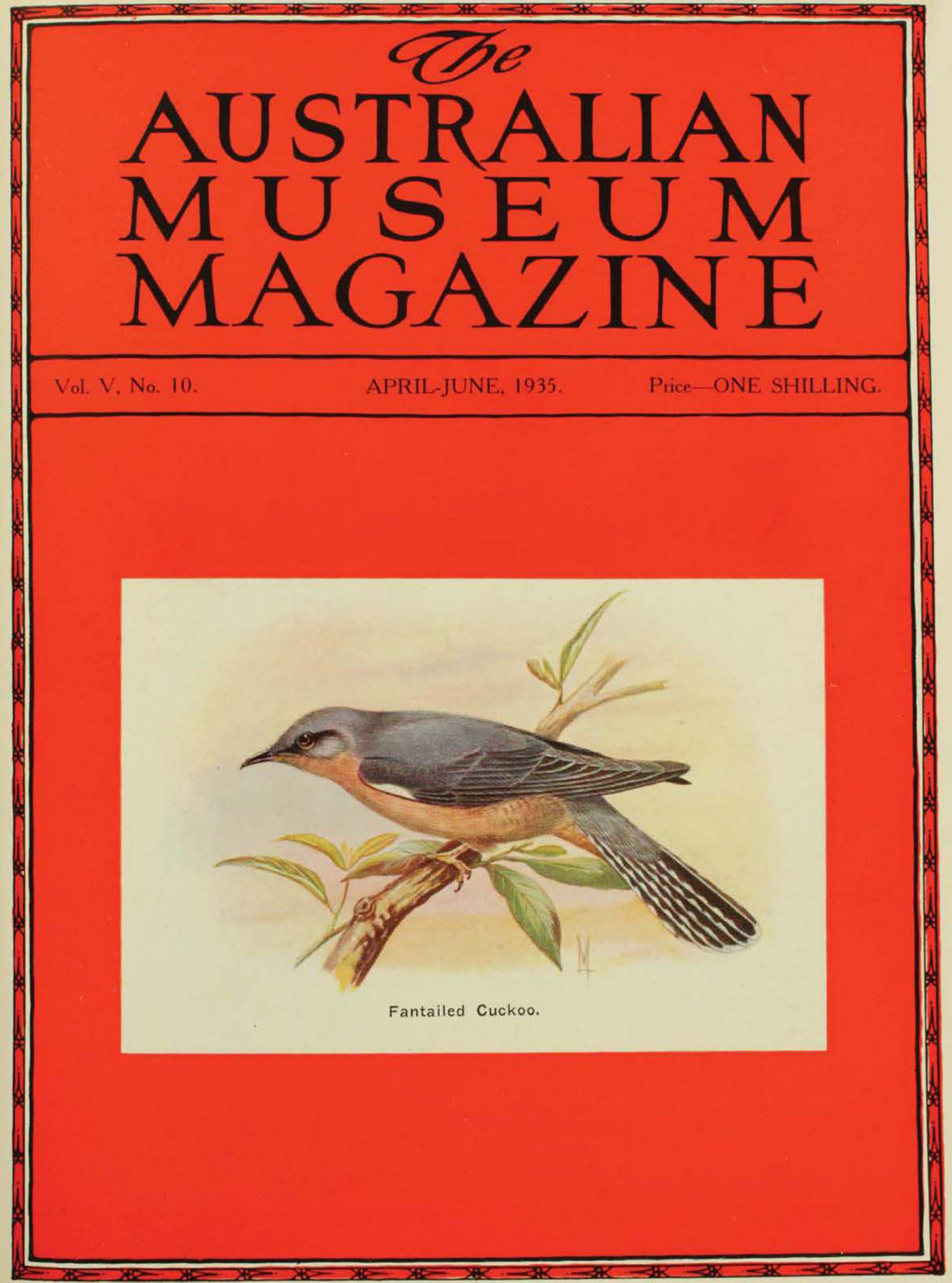

Registered at the General Post Office, Sydney, for transmission by post as a periodical. 


\section{THE AUSTRALIAN MUSEUM \\ HYDE PARK, SYDNEY}

BOARD OF TRUSTEES.

PRESIDENT :

F. S. MANCE.

GROWN TRUSTEE :

JAMES MCKERN.

OFFIGIAL TRUSTEES :

HIS HONOUR THE CHIEF JUSTICE.

THE HON. THE PRESIDENT OF THE LEGISLATIVE COUNCIL.

THE HON. THE COLONIAL SECRETARY.

THE HON. THE ATTORNEY-GENERAL.

THE HON. THE COLONIAL TREASURER.

THE HON. THE SECRETARY FOR PUBLIC WORKS.

THE HON. THE MINISTER OF PUBLIC INSTRUCTION.

THE AUDITOR-GENERAL.

THE PRESIDENT OF THE NEW SOUTH WALES MEDICAL BOARD.

THE SURVEYOR-GENERAL AND CHIEF SURVEYOR.

THE CROWN SOLICITOR.

G. Н. АВВОтТ, В.А., М.В., Сн.М.

E. C. ANDREWS, B.A., F.G.S.

GORRIE M. BLAIR.

C. GORDON MACLEOD, M.A., M.D., Сн.M.

G. A. WATERHOUSE, D.Sc., B.E., F.R.F.S.

\section{ELECTIVE TRUSTEES :}

F. S. MANCE.

THE HON. F. E. WALL, M.D., M.L.C.

PROF. A. N. St. G. BURKITT, M.B., B.Sc.

THE HON. H. M. HAWKINS, M.L.C., F.R.E.I., F.I.L.V. PROF. W. J. DAKIN, D.Sc., F.L.S., F.Z.S., F.R.Z.S.

FREDRICK W. MARKS, F.C.A. (ACSTR.).

MAJ.-GEN. SIR CHARLES ROSENTHAL, K.C.B., C.M.G., D.S.O., V.D.

\section{DIRECTOR :}

CHARLES ANDERSON, M.A., D.SC., C.M.Z.S.

\section{SECRETARY :}

W. T. WELLS, A.I.A.V.

\section{SCIENTIFIC STAFF :}

Mineracogy and Petrology. T. HODGE-SMITH. R. O. CHALMERS, A.S.T.C. Palceontology.

C. ANDERSON, M.A., D.Sc. H. O. FLETCHER.

Lower Invertebrates.

F. A. MONEILL.

A. A. LIVINGSTONE.

W. BOARDMAN.

Conchology.

TOM IREDALE.

JOYCE K. ALLAN.
Entomology and Arachnology.

ANTHONY MUSGRAVE, F.R.E.S. K. C. MCK EOWN.

Ichthyology.

GILBERT P. WHITLEY.

Amphibia, Herpetology, and Ornithology. J. R. KINGHORN, C.M.Z.S.

Mammalogy and Osteology.

ELLIS LE G. TROUGHTON.

Anthropology and Ethnology. ELSIE BRAMELI, M.A., Dip.Ed. F. D. MCCARTHY, Dip. Anthr.

LIBRARIAN :

W. A. RAINBOW.

PREPARATORIAL STAFF :

G. C. CLUTTON, Chief Articulator.

H. S. GRANT, Chief Taxidermist.

\section{HONORARY SCIENTIFIC STAFF :}

Zoologists.

PROF, T. HARVEY JOHNSTON, M.A., D.Sc

EDWARD F. HALLMANN, B.Se.

PROF, E. A. BRIGGS, D.Se.

H. LEIGHTON K ESTEVEN, D.Sc., M.D MELBOURNE WARD.

Ornithologists.

A. F. BASSETT HULL, F.R.Z.S.

K. A. HINDWOOD.

Entomologists.

G. A. WATERHOUSE D.Se., B.E., F.R.Z.S

H. J. CARTER, B.A., F.R.E.S.

T. H. GUTHRIE.

W. W. FROGGATT. 


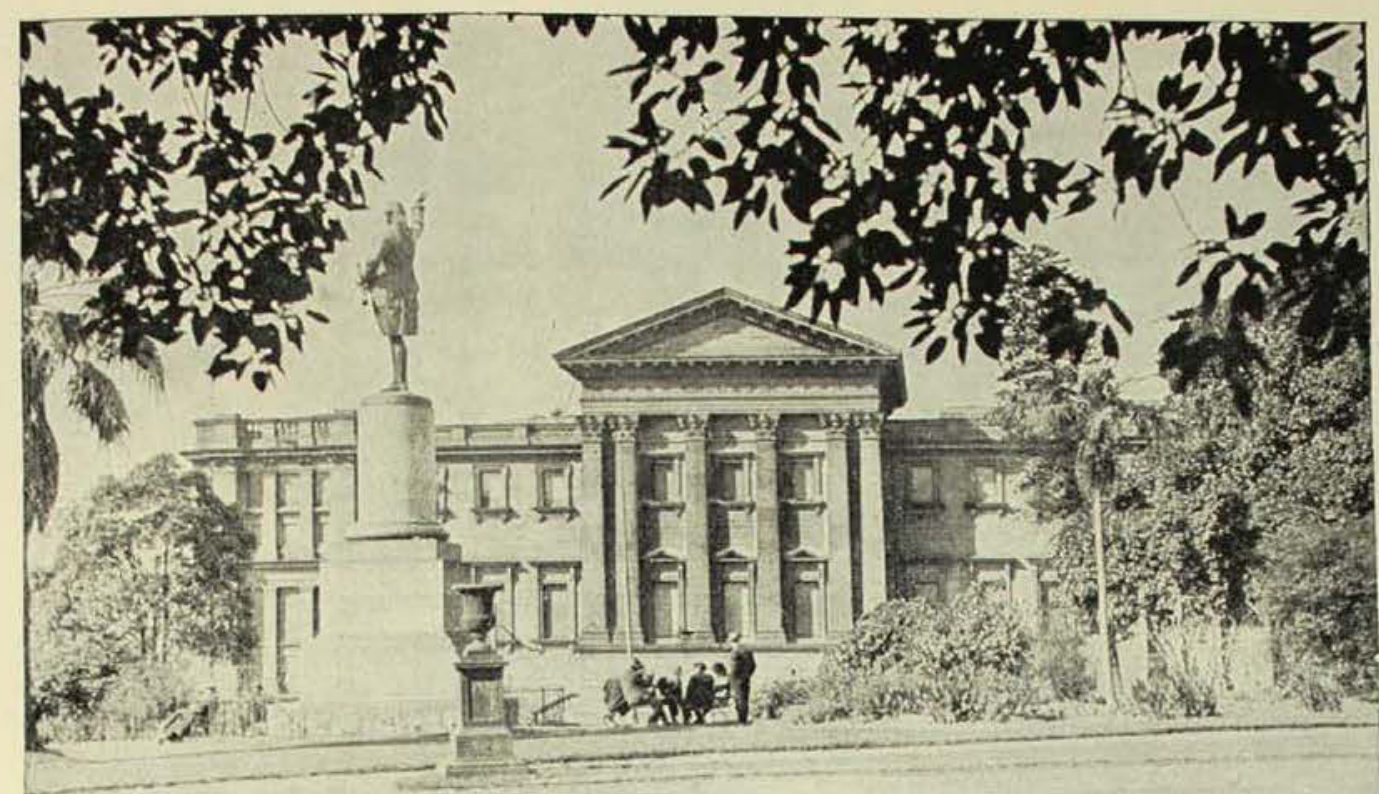

\section{THE AUSTRALIAN MUSEUM MAGAZINE}

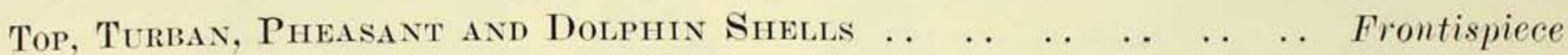
australiax Shells: Top, Turban, Pheasant and Dolphix Shelds-Joyce Allan 331

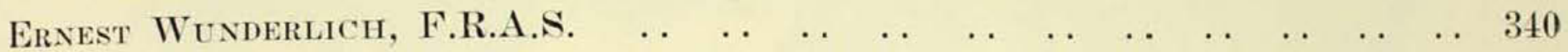
The Fish and the Ring: Ix Fable and Fact-G. P. Whitiey . $\ldots . \quad \ldots \quad \ldots \quad 341$

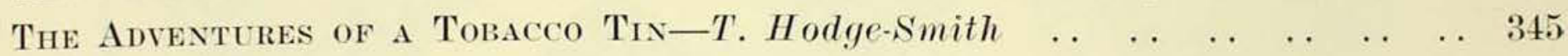

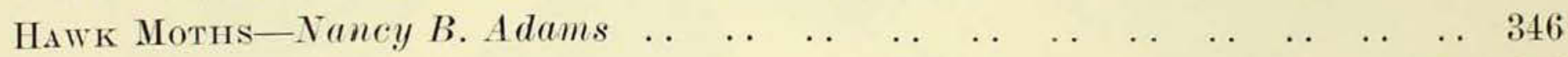

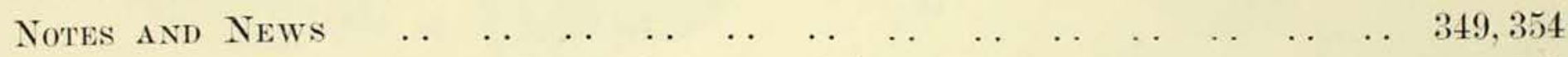
Caloundra: A Naturalists' El Dorado-Albert E. J. Thackway . . . . 350

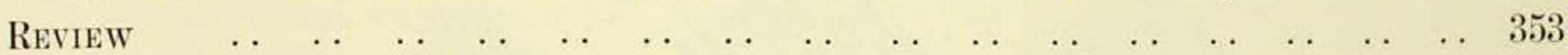

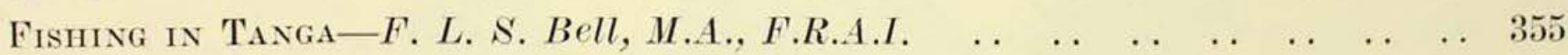
Wonders of the Ant World: Part I-Keith C. Mckeown $\ldots \quad \ldots \quad \ldots \quad \ldots \quad \ldots \quad 360$

- OUR FRONT COVER. The Fantailed Cuckoo (Cacomantis cinerascens Vigors and Horsfield) is by Lilian Med̄and. It is one of a series of post cards issued by the Australian Museum.

Australia is rich in cuckoos, and has one species closely related to the European Cuckoo, but even this does not utter the characteristic cuckoo note. The call of the present species is a melancholy trilling whistle. The bird is a lover of gullies and secluded places, but occasionally, especially in winter, comes out into the open country.

The Fantailed Cuckoo extends throughout Australia and as far north as the Aru Islands. It has the parasitic habit of most of its relatives, and does not make a nest for itself, but places its eggs in the nests of small insectivorous birds. The young cuckoo, on hatching, ejects its foster brothers from the nest so that it may have all the food which both parents can bring. The egg is pinkish-white, finely spotted with brown. 

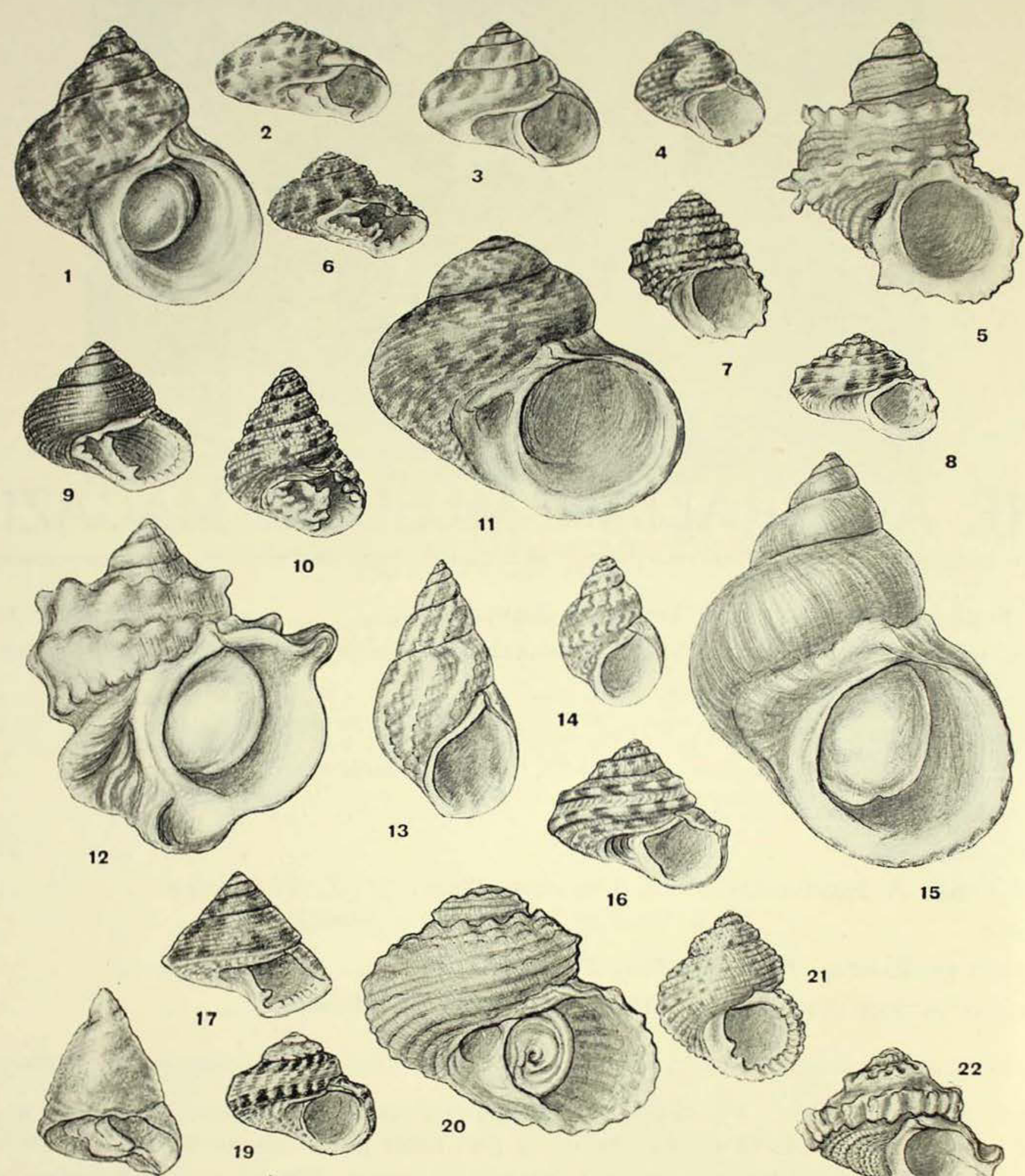

5
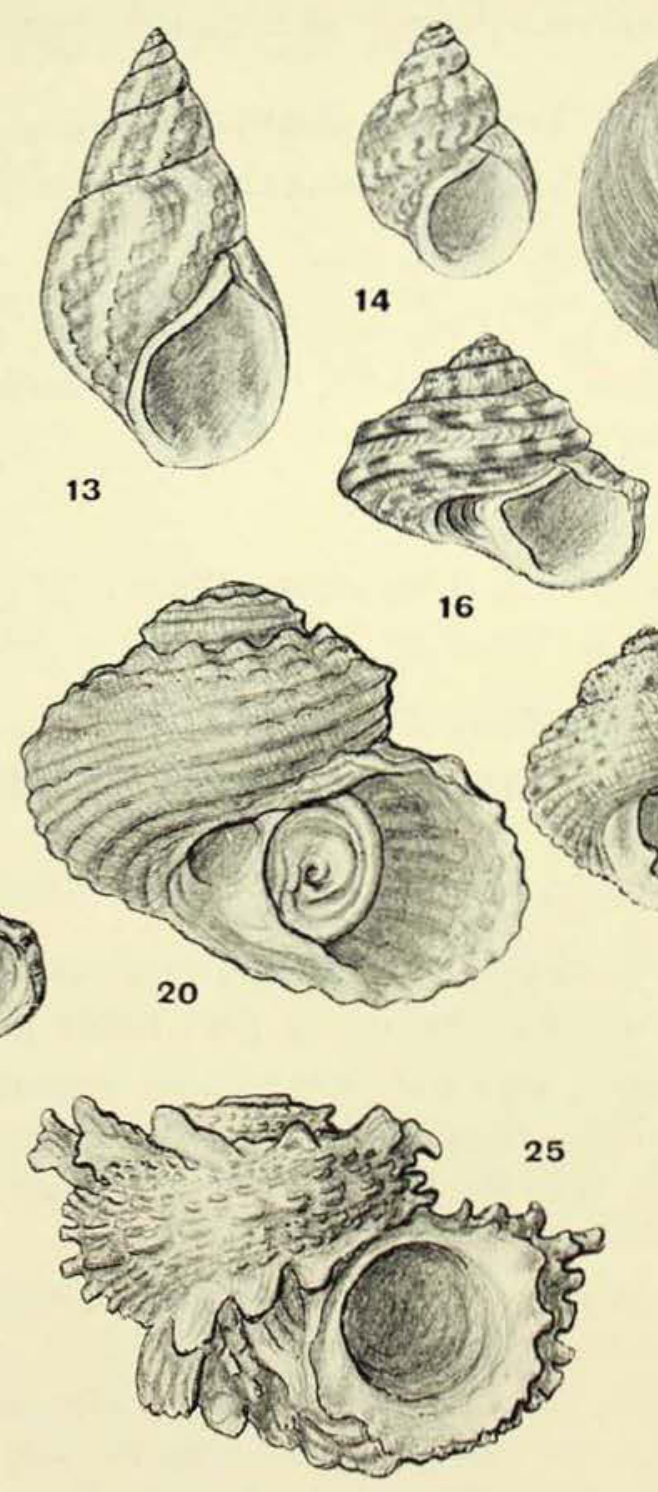

15
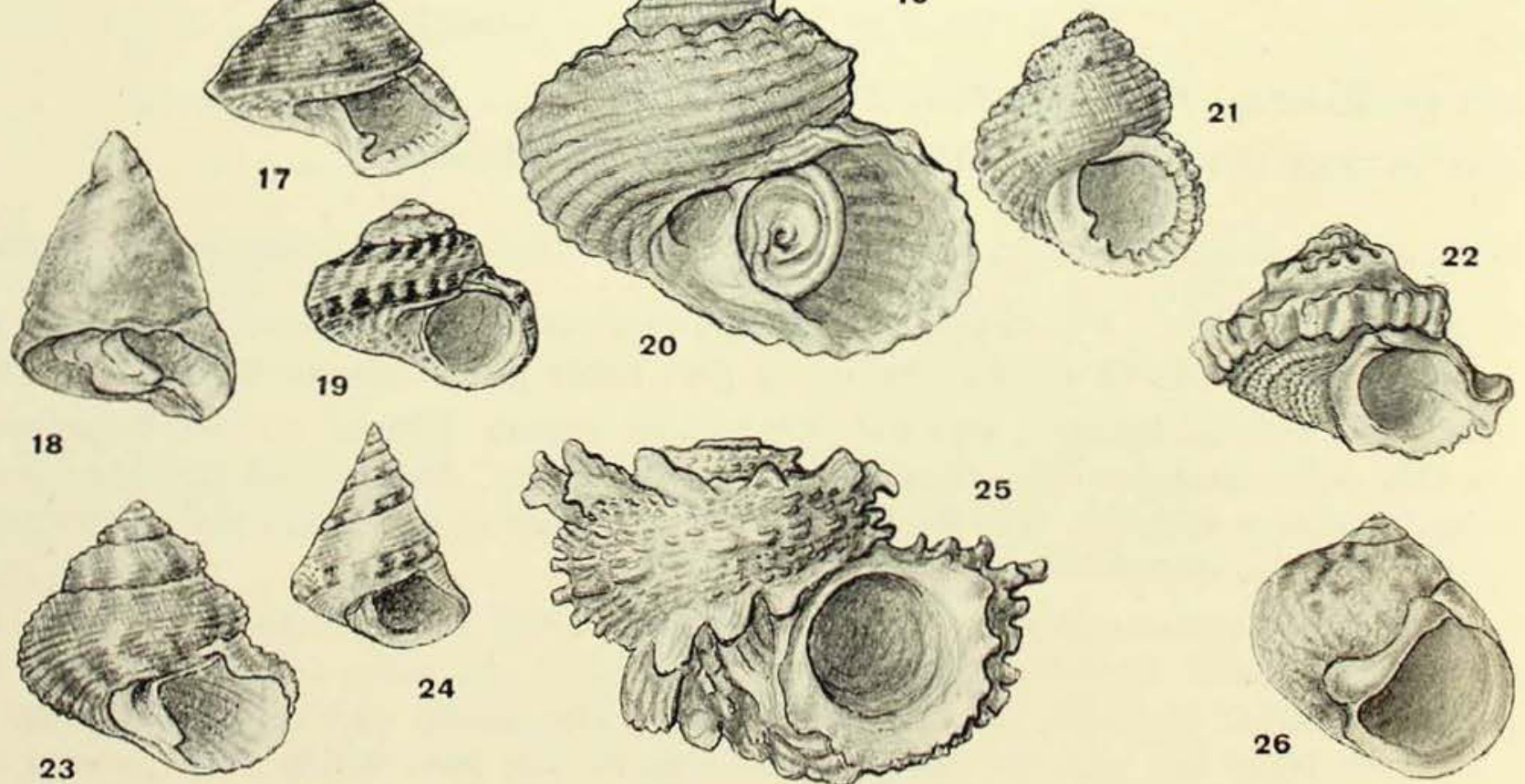

Top, Turban, Pheasant and Dolphin Shells. (See "Australian Shells", by Joyce Allan, page 331.)

[Joyce Allan, del. 


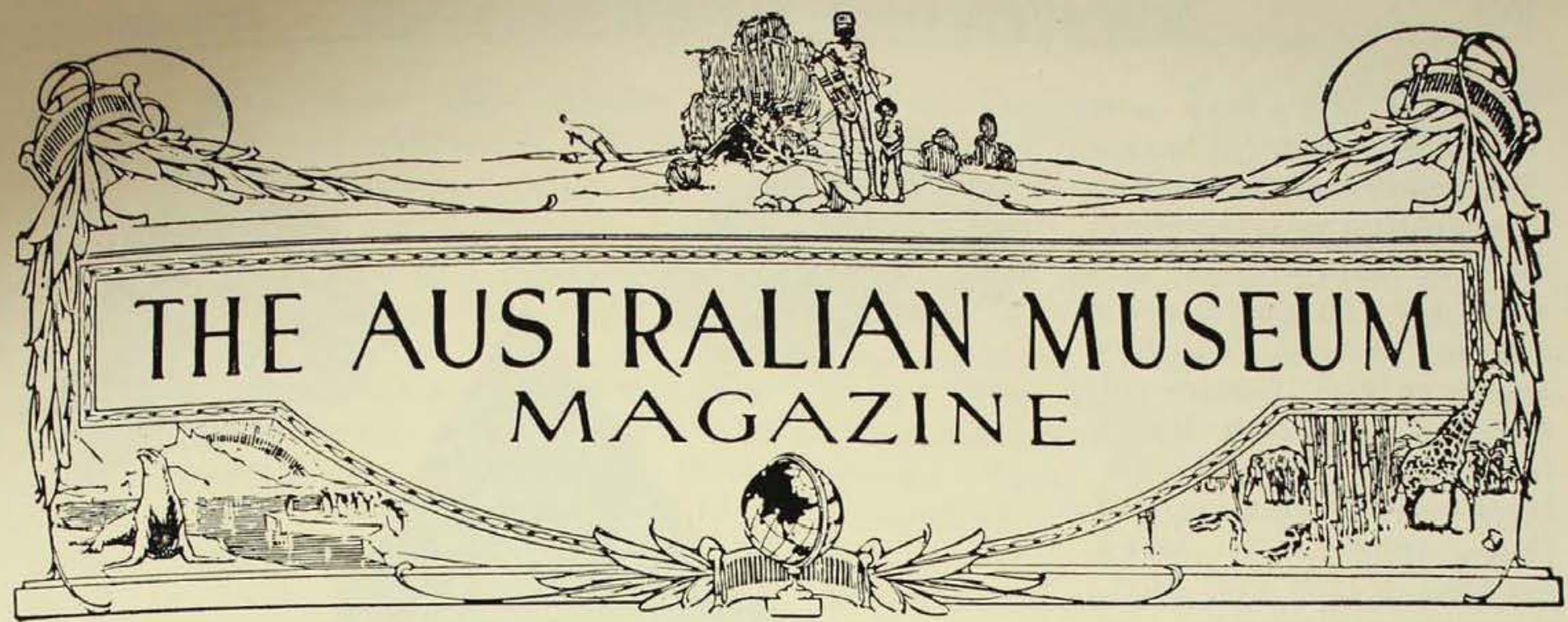

Published by the Australian Museum

College Street, Sydney

Editor: C. Anderson, M.A., D.Sc., C.M.Z.S.

Annual Subscription, Post Free, 4/4

VOL. V, No. 10.

APRIL-JuNe, 1935.

\section{Australian Shells}

\section{TOP, TURBAN, PHEASANT AND DOLPHIN SHELLS.}

\section{By Joyce Allan.}

\section{THE TOP SHELLS.}

\section{$\mathrm{T}$} HE very large family of Top shells. or Trochidæ, contains many genera. and species of large and small shells living in shallow water along coasts or in deeper water. A great number of the small prettily marked shells found between tides, under stones, and on weeds in Australia belong to this family. The shells are mostly conical or rounded, and practically all are highly coloured, quaintly marked, or delicately sculptured, although a protective epidermis often hides this.

They are almost all brilliantly nacreous, noticeable inside the aperture, and, when the outer surface is removed by an acid solution, the exposed undersurface rivals true mother-of-pearl. Because of this iridescence, numbers of the smaller more pearly ones are strung together as necklaces or are used for other purposes. The larger and stronger species are used in the manufacture of buttons or other mother-of-pearl articles.
Top shells are chiefly a tropical and subtropical family, the largest species occurring in the warmest seas; they are vegetable feeders, and all have a horny operculum, generally fitting neatly into the aperture of the shell.

\section{TROCHOID SHELLS.}

Among the principal genera found in Australia is Trochus or True Top shells. The largest species of the family are found in this genus, and some of them are strong enough to make excellent mother-of-pearl articles. To this genus belongs the most important shell of the family, the Trocas or Button Shell (Trochus niloticus), for from it is manufactured the world's supply of small pearl buttons. About four inches high, the shell has numerous whorls, and, although the outer surface is covered when alive with a thin yellowish-brown epidermis, when this is removed the shell is found to be white, longitudinally striped in a con- 
spicuous manner with crimson or reddish-brown. The interior of the mouth is beautifully pearly, showing the suitability of this shell for the purpose for which it is used. The very solid animal carries on its foot a brown horny operculum. There is a distinct male and female, and they appear to breed between March and July, the eggs being laid on rocks or glued to weeds, and the shell matures between the second and third year. The Trocas lives in shallow water on reefs in Queensland and north-west Australia, the East Indies, the Philippines, New Guinea, New Caledonia, and other islands of the south Pacific, but chiefly along the Great Barrier Reef, where it quietly browses on the minute algæ forming its food. Normally

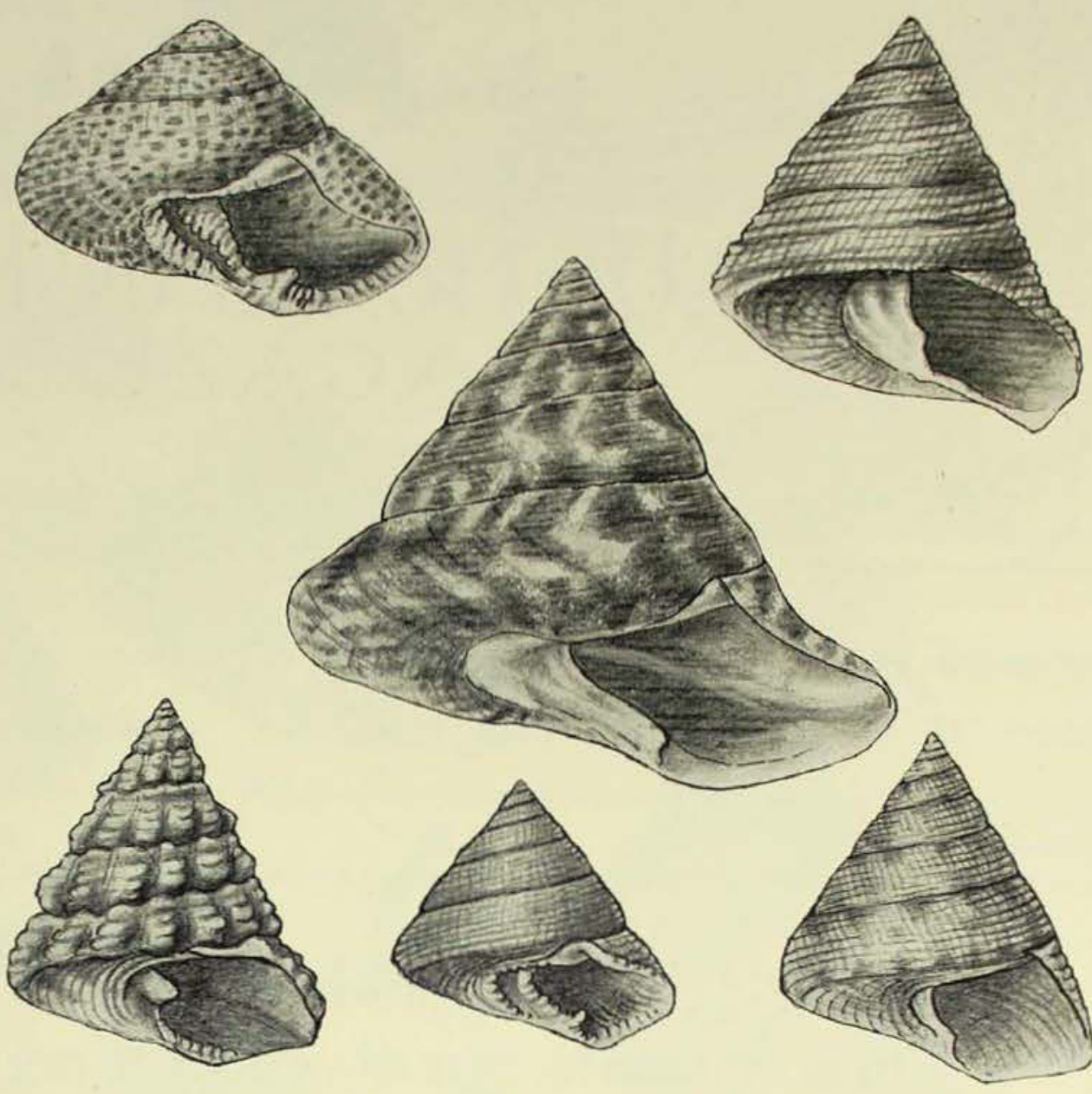

On the upper left is figured the Speckled Red shell and on the right the Lined Top Shell. The large figure in the centre is the Trocas Shell, and the three lower figures are the Latticed Top Shell, Mauger's Top Shell, and Meyer's Top shell, respectively. [Joyce Allan, del.

they are exposed at low tide, but occasional specimens are found in deeper waters.

As the Trocas shell and its fishing has been written up in previous parts of this Magazine, the reader is referred to them for more detailed information. It need only be mentioned here that all the Trocas shell collected in Australia is shipped to Japan, where it is made into buttons for export round the world. Trocas shell buttons can be recognized by the red markings on the back of the buttons; they are mostly used for shirts. The animal, after extraction from the shell, is dried and smoked and sent to China and Singapore, where it is considered a great delicacy as a basis for soups and stews. Trocas meat may fetch as much as $£ 60$ a ton.

A shell very similar to Trochus niloticus is Trochus maximus, which is, however, more conical but less heavy.
This does not occur in Australia, but is found chiefly in the Philippine Islands, where a small percentage of it is used with the true Trocas shell in the manufacture of buttons.

Another large Top shell is whitish with a green tinge and ornamented with very narrow, close, obliquely descending reddish-purple lines. This is the Lined Top Shell (Trochus lineatus), a smooth form of $T$. hanleyanus, and many of the whorls, finely granulated in the adult specimens, are nodulose in young ones. It is found in Western Australia, and grows to a height of almost two inches.

Latticed Top Shells (Trochus fenestratus) are well known, greenish-white, pyramid-shaped shells, about one and a half inches high, found in north Australia and the south Pacific islands. The whorls are covered with fine oblique wrinkles and additional longitudinal 
knob-like ribs make this species distinguishable from others of the genus.

Small shells with granulated surfaces and the columella of the mouth with a tooth-like fold above and terminating in a tooth at the base, form the genus Clanculus, members of which are very common in rock-pools and on weed. The two largest of these are Mauger's Top Shell (Clanculus maugeri), a solid, thick, red-brown shell, dotted minutely with a darker colour, about an inch high, and found in New South Wales, and the Speckled Red Shell (Clanculus undulatus). This species is the largest of the Clanculoid Top shells, and occurs in Tasmania and the States of southern Australia. It is very handsome, rose or brown coloured, radiately striped or irregularly maculated with blackishbrown, and reaches a height of one inch and a breadth of an inch and a half. Two very similar species are the little Strawberry Top Shell (Clanculus unedo) (Frontispiece, fig. 10), from Queensland waters, and Clanculus stigmatarius, which occurs in the south Pacific islands and also Queensland. The Strawberry Top Shell, which is about three-quarters of an inch high, is higher and narrower than the other species, and its colour, red or red-brown dotted with black, is more pronounced.

The Dark Purple Top Shell (Clanculus atropurpureus) (Frontispiece, fig. 9), from Queensland and the south Pacific generally, is easily recognized. It is a solid, dark purple or brown species, with encircling fine granulose liræ. A marginal rib bearing four white teeth, one larger than the others, borders the umbilicus. An average shell is about a quarter inch high.

Many colours are represented in a very common little Top shell (Clanculus plebeius), which is only one-quarter inch high and is found on rocky shores in Tasmania and southern Australia generally, especially in Victoria. Black and white dots on a ground colour of pinkishbrown, grey or yellow, often form radiating lines on the upper surface, and zigzag ones on the base. Four coarse beaded lire encircle the angular body whorl, as well as minute concentric striations.

Perhaps the commonest Clanculoid Top shells found in rock-pools round Sydney are the Keeled Top Shell (Clanculus omalomphalus (Frontispiece, fig. 17), the Florid Top Shell (Clanculus floridus) (Frontispiece, fig. 6), and a more conical species than these two (Clanculus clangulus). The first named has a sharp keel on the periphery of the body whorl, is about half an inch high, and has brown blotches on a greyish-brown ground colouring. The Florid Top Shell is rosy pink and is much flatter than the others. Its whorls are strongly granulated, and there is a strong biplicate tooth on the columella with a wide projection in the middle, and a strong tubercle near the upper angle of the finely plicate outer lip. The colouring of Clanculus clangulus is brown, or more often a bright emerald green, with a rosy apex and the upper surface marked with radiating flame-coloured bands. There are several species, such as maxillatus, personatus and flabellatus, closely allied to these, occurring in Australian waters, and a close examination of them is necessary, especially of the teeth structures within the mouth, for differentiation.

\section{PERI WINKLES.}

Amongst the commonest shells found on the high water mark round the Australian coast are the periwinkles, belonging to the genus Monodonta. Globose and smooth, or else spirally ridged, the periwinkles are dark coloured or marked with light spots or stripes on a dark ground. The animals are eaten or used as bait by fishermen. In New South Wales the rocks along the coast are in parts literally covered with a thick, lustreless, dark periwinkle, conspicuously marked with longitudinal wavy white marks. This is Monodonta obtusa, the common periwinkle, and is so well known that further description is unnecessary. It is about one and a half inches high, is found in eastern Australia generally and in 

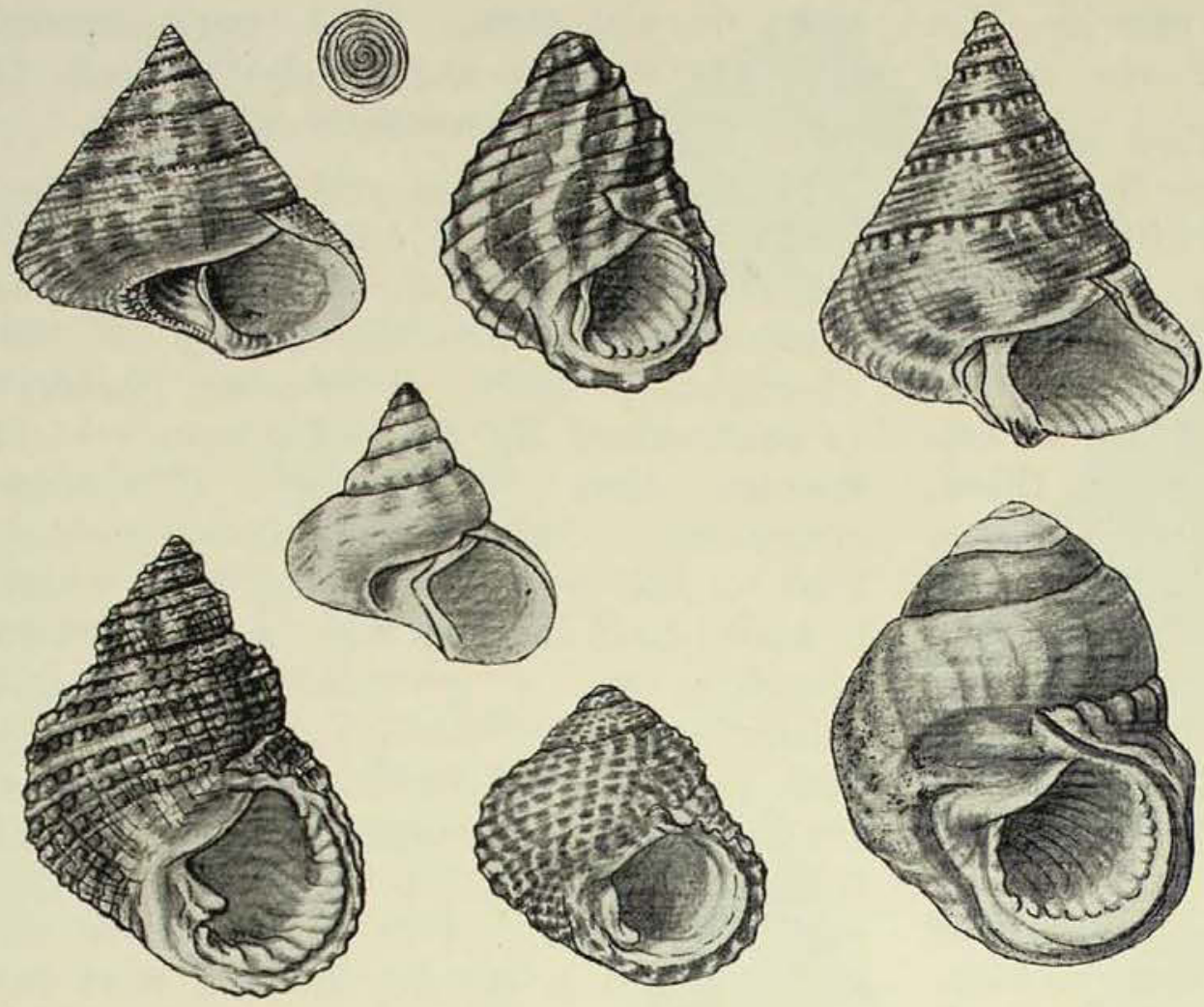

The Imbilieated Top Shell, with its operculum, is on the upper left, and a Queensland species (Calliostoma speciosa) on the extreme right. In the centre of the upper row is the common Sydney Periwinkle. The three periwinkles in the lower row are the Lipped Periwinkle, a small South Australian species (Monodonta concamerata), and the Rough Perivinkle from Western Australia. The small shell between the two rows is the Slender-spired Top Shell.

[Joyce Allan, del. and in colour. It is a solid shell, its whorls are encircled with coarse, granulose lira, and the outer margin of the white porcellaneous mouth is plicate and green. There is a square tooth at the termination of the short columella. In colour, this species is mostly greyish-pink or green, mottled or striped with black, sometimes red. Western Australia has a bluishblack periwinkle, the Rough Periwinkle (Monodonta rudis), the apex of which is usually eroded, giving it a chalky - white appearance. The columella is white, and the outer lip of the pearly mouth is margined with black. This species is smoother than other forms, and lacks the coloured stripings common to many. It is about the same size as the Common Periwinkle.
Tasmania, and when it occurs in sheltered muddy bays is usually a smoother form than the form found on rocky shores.

A species closely allied to this occurs in Tasmania and the southern States, but is easily distinguished from it by the more prominent spiral ridges, less in number than in the previous species, which encircle the whorls. This is Monodonta constricta, which is very common on rocky shores. Another periwinkle (Monodonta concamerata), which lives in southern Australia generally, is more squat than the common forms, and has finer and more numerous lines on it, sometimes the black, sometimes the light coloured ones predominating. There are several other smaller species of periwinkles occurring on the Australian coasts which closely approach these in appearance, but are not so common.

The Lipped Periwinkle (Monodonta labio) of Queensland and the south Pacific islands, is quite different from the others both in general appearance
In rock-pools along the New South Wales coast is often noticed a small olive coloured, rather thin shell, less than half an inch high and with strong spiral ridges and fine striations on the whorls. This is the Little Top Shell (Eurytrochus strangei), belonging to a genus of very small, spirally lirate, round mouthed shells common to Australia and the islands of the south Pacific.

\section{KELP SHELLS.}

Kelp shells rank amongst the best known of the Top shells, as they are frequently found washed up in great numbers on beaches. Normally they live on weeds, chiefly kelp weed, or in rock pools, and they are easily distinguished from other genera by their bright varied colouring, brilliant iridescent interiors, and their elongated shape. Several species of the genus Cantharidus are used ornamentally, especially Cantharidus bellulus, the Necklace Shell, and the True Kelp Shell (Cantharidus eximius). The latter, the largest of the kelp shells, is 
found mostly on large kelp weed in southern Australia and Tasmania. The beautiful blue, green, and red iridescence which underlies the variable coloured outer surface, is seen in the mouth of the shell. It is about one and a half inches high.

The Necklace Shell lives on smaller weed than the previous species, and is found in depths of eight to ten fathoms. The shell is elongated and pointed, very polished, and is pink or yellowish-green with red or lighter stripes running down the shells in pairs. When the outer surface of the shell is removed by acid, the exposed nacre is beautifully tinged with green, purple, and red. Though found principally in Tasmania, this small shell occurs also in other southern States, though not in New South Wales.

The shells are threaded into necklaces and sold in Hobart shops to tourists. Young shells appear on the weed about January or February, and, when they escape the ravages of their greatest enemy, the parrot fish, grow rapidly.

The commonest kelp shell is the Banded Kelp (Cantharidus fasciatus). In a handful collected from any sandy beach there will be much colour variation. The shell may be creamy-white or pink, ranging to purple with spiral bands of purple-red or brown, or, on the other hand, may have narrow oblique zigzag stripes of a contrasting colour. The Banded Kelp Shell is sometimes called the Silver Shell, because of the silvery iridescence of the undersurface. It grows to nearly an inch in length, and occurs on all southern Australian shores.

Of the narrow elongated forms of kelp shells, the best known is the small Lined Kelp Shell (Cantharidus lineolaris), less than half an inch high, which lives on the New South Wales coast. The broader based type of kelp shell is represented in New South Wales by a very wellknown species, Comtesse's Top shell (Cantharidus comtessei), in southern Australia and Tasmania by the Conical Shell (Cantharidus conicus), and in Western Australia by the Crimson-striped shell
(Cantharidus lesueri). Comtesse's Kelp Shell is found in practically every rockpool or on weed along the New South Wales coast, where it is very common, and it occurs also in the southern States. It is about three-quarters of an inch high, is brown ornamented with alternate black and white granules, and the brilliant iridescence of the mouth is partly hidden by a cloudy white deposit. The Conical Kelp Shell is about the same size as the previous species, is pink or grevish-white with a crimson apex, and has dark redbrown stripes ornamenting it. It lives in shallow water in southern Australia and Tasmania, but has not yet been recorded from New South Wales. Fine spiral striations and swollen whorls are strong characters of the Crimson-striped Top Shell, the range of which extends from Western Australia round to southern Australia. Wide crimson stripes on the white or slightly bluish background, and a crimson band on the columella, umbilicus and along the outer lip of the mouth, are responsible for its vernacular name. It is about half an inch high.

One of the commonest small shells found in weed-filled rock-pools along the New South Wales coast is the Little Kelp Shell Cantharidella picturata (Frontispiece, fig. 4). Less than a quarter-inch high, this pretty species varies considerably in colour, but is frequently white. with interrupted crimson-red longitudinal flames ranging from the periphery to the base, or is yellowish-white with red on the encircling lirx. Some specimens are almost black, but all have an iridescent interior with the columella and umbilicus tinged with green.

Amongst the many small types of shells found in pools, on weeds, or dredged in deeper water, are those forming the genera Monilea, solid depressed shells with a callous ridge revolving on the inner side of the whorl, within the umbilicus, and the surface spirally lirate or striate; Minolia, thin, broadly umbilicated, finely sculptured shells, very like those of the previous genus, but without a spiral ridge within the umbilicus; and Notogibbula, 

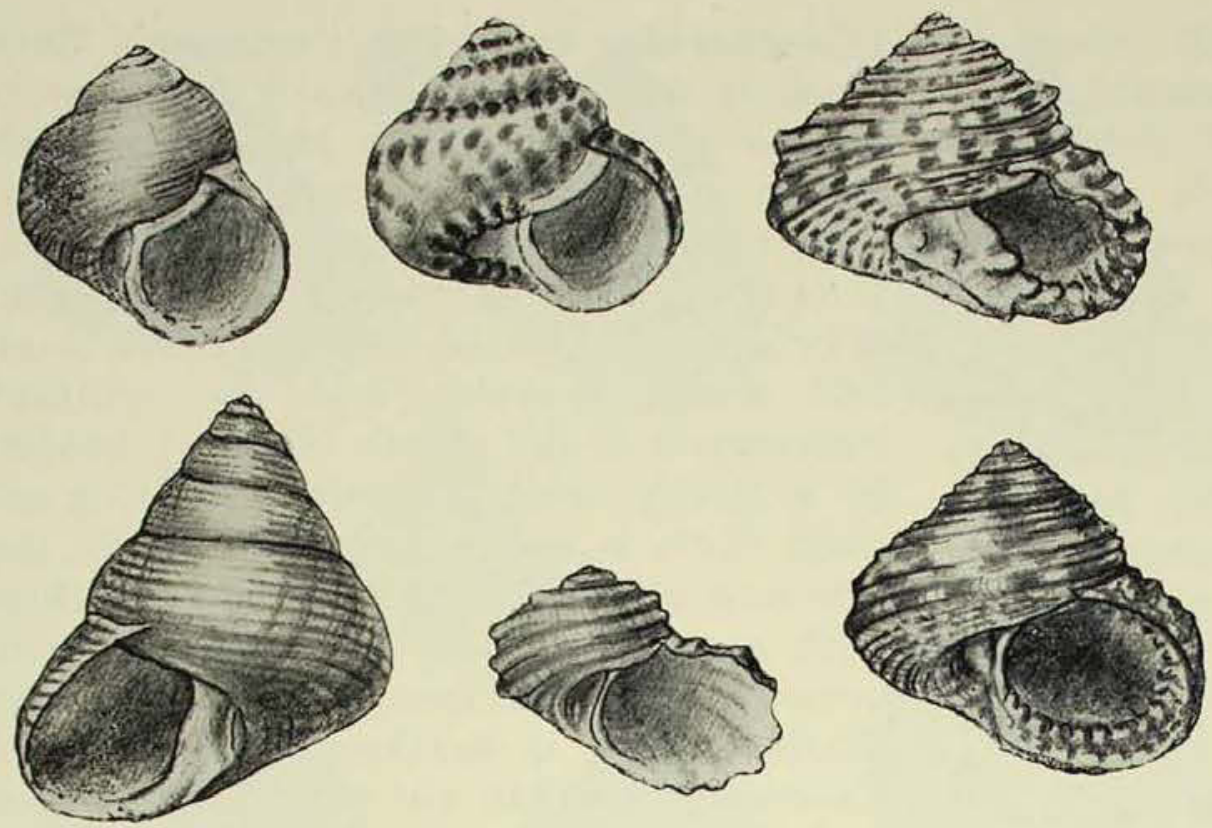

From left to right are figured in the upper row a small Top shell from Tasmania (Minopa tasmaniea), the Crowned Top Shell (Isanda coronata), and a well-known little Top Shell (Clanculus plebeius). A form of left-handed shell, the Reversed Top Shell, is on the lower left; next to it is a small Trochoid (Fossarina patula), and the remaining figure is of a very common species (Eurytrochus strangei).

[Joyce Allan, del. thinner than shallow water forms, and no species are figured in this article.

Solid, globose, smooth shells with short spires and a heavy callus extending from the inner lip of the mouth to the umbilicus, comprise the genus Chrysostoma. They are found in tropical seas. The species figured is the Orange-mouthed Top Shell (Chrysostoma para. doxum) (Frontispiece, fig. 26), from Queensland and the south Pacific islands. It is about three-quarters of an inch high, is white with red reticulations and mottlings, and sometimes darker patches, and has a striking orange-red mouth and callus. Two very similar very small, attractively marked trochoid shells of thin texture and with angulated whorls. In the genus Euchelus, the shells are solid, turbinated, with an elevated spire and thick lip to the aperture; the columella has a tooth near the base and sometimes a notch below. The surface of the shell is finely sculptured. The genus Tullorbis is very close to this in appearance, but has stronger revolving lines and tubercular ornamentation on the shells. To the genus Isanda belong small, compact, polished, porcellaneous shells, with the margin of the umbilicus crenate.

Included in the genus Calliostoma, one of the largest genera in the family Trochidæ, are species inhabiting not only shallow water but very great depths. The shell is generally conical, with an angulated periphery and simple columella, which in some species is slightly toothed in its lower part. Like Calliostoma in general appearance, the genus Astele has, however, a very wide umbilicus. Astelena resembles a small Astele with more rounded whorls and a slender spire. The genus Benthastelena is the representative of the deep sea forms of Trochoids, which are only rarely trawled or dredged. The shells are delicately sculptured and genera are Camitia and Umbonium, both of which possess very depressed, smooth, often shiny, heavily patterned shells, but in Camitia they have a projecting tooth on the columella as in the genus Clanculus.

Figured on the frontispiece is a small conical-shaped shell (Calliostoma monile) (Frontispiece, fig. 24), about three quarters of an inch high. It is creamishyellow and shiny, with a white band striped with mauve on the periphery and on a ridge immediately above each suture. This species belongs to the family Trochidæ, and occurs in Western Australia. It has been recorded also from New South Wales.

In Western Australia is found Monilea preissiana (Frontispiece, fig. 16), about one-quarter inch high, and distinguished by two strong spiral ridges on the body whorl. Its colour is whitish, strongly marked with rose or brown lines and spots. The Two-keeled Top Shell (Monilea bicarinata) from New South Wales is more elevated, and has broad flames of olive and pink down the shell. The Subdued Top Shell (Monilea vitiliginea) is not characterized by any strong colour marking or sculpture. The whole shell is 
finely spirally striated and has white or light brown maculations on a pale yellowbuff ground colour. It is half an inch high and lives on the coast of South Australia.

The white or pinkish whorls, especially the body whorl of a small shell from New South Wales, Monilea pulcherrima (Frontispiece, fig. 8), are stained and spotted with crimson. The rounded whorls of another small New South Wales shell, Minolia bellulus (Frontispiece, fig. 3), have broad flame-coloured bands on them. The base of the shell, however, is white and the umbilicus is wide. This species is found in shallow water, but different forms occur in deeper water.

The Many Coloured Top Shell (Notogibbula lehmanni) (Frontispiece, fig. 19) is remarkable for its colouring and design. The biangulated body whorl has on it transverse white, red, or purple interrupted lines, and at the periphery and sutures are white bands. Below these bands are a row of alternate dark and white spots, and the base is white, tessellated with red. It occurs in Western Australia and grows to about one-quarter inch high.

Sharp, close, spiral ribs, with deep spaces between them, and longitudinal lines forming beads on the ribbing, form the sculpture of a solid lustreless shell of uniform white colour marked with brown. This is Monilea lentiginosus (Frontispiece, fig. 23), found in New South Wales and Queensland, and it is about an inch high.

In Tasmania is found a very small pale buff Top shell (Minopa tasmanica), as well as Meyer's Top Shell (Calliostoma meyeri) and the Umbilicated Top shell (Astele subcarinata), both rather similar in shape and colour, and in Queensland another somewhat similar species (Calliostoma speciosa) occurs. The most extraordinary member of the genus Calliostoma, however, is the Reversed Top Shell (Calliostoma incertum), a pale buff shell about three-quarters of an inch high, which is found in shallow to deep water in Victoria, Bass Straits, and New South Wales. In this shell, contrary to all other Trochoids, the mouth, instead of being on the right side of the shell, is on the left.

The Beaded Top Shell (Euchelus baccatus) (Frontispiece, fig. 21) is very common in shallow waters of Australia, particularly round the New South Wales coast. It is about half an inch high and is pinkish-grey in colour. In northern Australia a larger black relative (Euchelus atratus) is found.

False-beaded Top Shells (Tallorbis ampullus) (Frontispiece, fig. 7), less than an inch high, are found in New South Wales and Western Australia, and have red beading on a ground colour of white. In southern Australian waters generally lives the Slender-spired Top Shell (Astelena scitulum), a small yellowishshell, obscurely marked with brown. Two northern Australian genera, Camitia and Isanda, are represented by the Wheel Shell (Camitia rotellina) (Frontispiece, fig. 2), a beautifully marked, golden brown, polished shell, which lives on the reefs of Queensland, and Isanda coronata, the Crowned Top Shell. This is only an eighth of an inch high, very polished and solid, and quite distinct from other shells.

There is a genus of very small Trochoid shells with wide umbilicus which live on rocks mostly above high water mark. In New South Wales the genus is represented by Fossarina patula, and in Tasmania by a smoother form, Fossarina petterdi, which is very common on rocks and in mussel beds.

DOLPHIN SHELLS.

These shells, which resemble turbanshaped Top shells, belong to the family Angariidæ. They are solid, pearly within, and the loosely coiled whorls are ornamented by scales, spines, or spiral striation. The family is tropical, and possesses only one main genus, Angaria, which in turn only has a few species, the best known of which is the Laciniated Dolphin Shell (Angaria delphinus) (Frontispiece, fig. 25), occurring in 


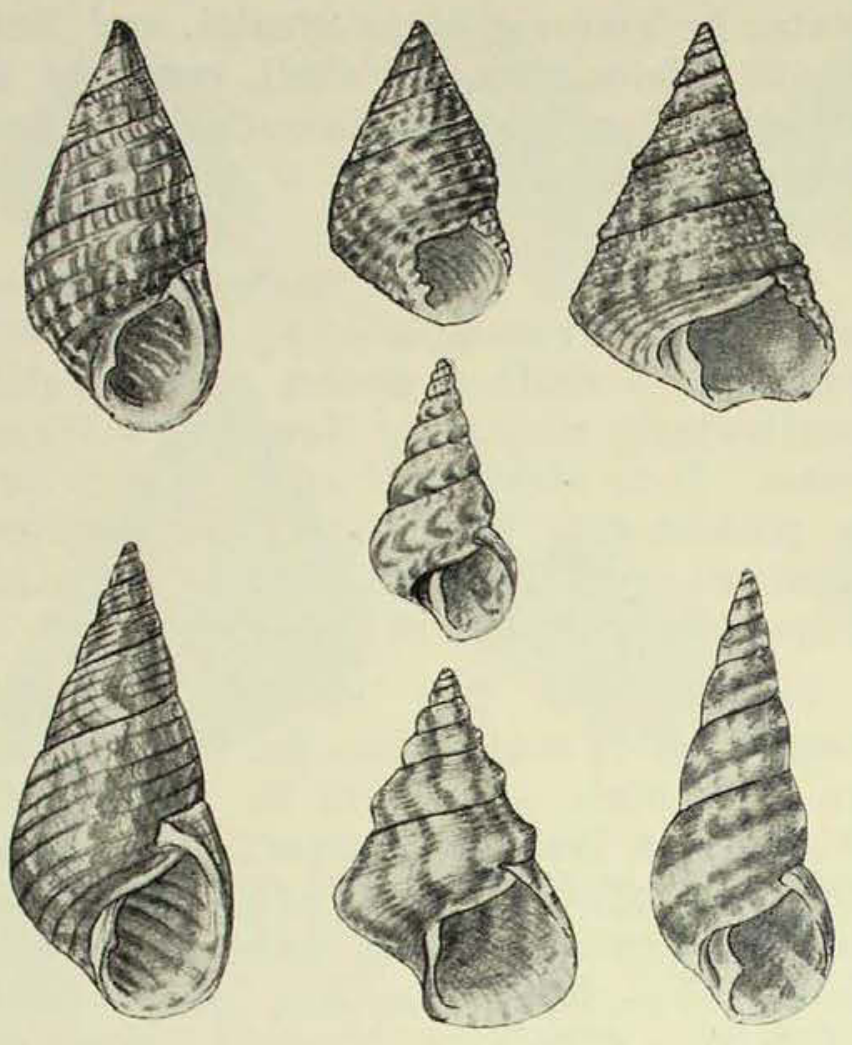

Kelp shells are the best known of all the Top shells. The Necklace shell is figured on the upper left, next to it is the conieal Shell, and the last figure in the upper row is a very common Sydney shell, Comtexse's Shell. Alone in the centre is the small Lined Kelp Shell, and in the lower row are the True Kelp Shell, the Crimson-striped shell and the Banded Kelp Shell. [Joyce Allan, del.

northern Australia, the south Pacific islands and the Indian Ocean. It may grow as large as nearly three inches in diameter.

\section{TURBAN SHELLS.}

Amongst the many pretty shells found in Australia and the south Pacific islands, a large percentage are Turban shells, easily distinguished from those of other families by their turban shape, and the solid thick operculum which is attached to the foot of the animal and completely blocks the entrance to the shell when the animal withdraws within it.

Turban shells (family Turbinidæ) inhabit the shores of warm oceans and are vegetable feeders. The main genus is Turbo, possessing the characters of the family, and is represented by many wellknown shells. Of these, the Green Snail (Turbo marmoratus) (Frontispiece, fig. 12 ), the giant of the family, and inhabit- ing the south Pacific islands and the Philippines, is perhaps the greatest favourite with curio dealers and collectors. When the outer surface of the shell is removed, the opaline tints of the pearly undersurface make the shell a handsome ornament for cabinets. On account of the size, solidity, and the pearly undersurface, the shell is much in demand for button making and the manufacture of other mother-of-pearl articles. The animal also is utilized, and is considered by many an appetizing food. In the Philippine Islands especially the shell is collected in considerable numbers annually for both these purposes. The whorls of this well-known shell are square-shouldered and knobbed, and the large heavy operculum is white. Green Snails may reach eight inches in height and diameter.

Another large species of the family is Turbo jourdani (Frontispiece, fig. 15), a shell not distinguished by any ornamentation whatever, but easily recognized on account of its size, rich brown colour, and large mouth, closed by a strong white operculum, similar to that of the previous species. This species comes from southwestern Australia.

There are several small species, about two to three inches high, which occur in Queensland and the south Pacific islands. These are rather similar in shape, but have distinguishing characters sufficient to enable them to be separated. Of these, the best known species, the Yellow Mouthed Turban Shell (Turbo chrysostomus) (Frontispiece, fig. 5), is figured in this article. As its vernacular name implies, it can be recognized by its bright yellow mouth. A flatter small Turban shell, which occurs in Tasmania, Western Australia and New South Wales, is Turbo undulatus (Frontispiece, fig. 11). This is generally a uniform brown-black colour, or it may have radiations of olive green on a lighter ground. When present these colour bands are most noticeable on the base of the shell.

The best known of all the Turban shells, however, is the Cat's Eve Turban shell (Turbo petholatus) (Frontispiece, fig. 1). 
This is a beautiful polished species, varying considerably in colour and noted principally for its very polished, richly coloured operculum, the "cat's eye", which is collected for manufacturing into jewellery, such as rings, bracelets, and brooches. The Cat's Eve Turban Shell is found in Queensland and the south Pacific islands, where its colour ranges from yellow, red, and black, sometimes being uniform, and at other times mottled, marbled or lined. The "cat's eye" is a rich dark green and brown. Along the New South Wales coast the common Turban shell is the Sydney Turban (Turbo stramineus) (Frontispiece, fig. 20), a flat green species, heavily sculptured with close set radiating longitudinal lines. In the mouth a strongly ridged white operculum fits tightly. The Sydney Turban Shell is found below low water, tightly wedged in rock crevices amongst weeds. The animal is sometimes eaten by fishermen and was a popular food of the aborigines.

Conical shells, with flat bases and having their whorls often keeled and spiny at the periphery, belong to the genus Astraca, and are sometimes known as Star Shells. The common New South Wales form is about one and a half inches high, is not spined, except in its very early stage, and masses in numbers on rocks exposed at low tide. On account of this segregation, the New South Wales species (Astraca tentoriiformis) (Frontispiece, fig. 18) is often known as the Tent Shell because numbers, fastened firmly to the rocks, look like a miniature encampment. A flatter species of Star Shell (Astrea fimbriata), with spines along the periphery of the whorls, also occurs in New South Wales. From Western Australia comes a rather large species (Astrcea rotularium) (Frontispiece, fig. 22 ), with a double row of numerous, small, knob-like spines along the periphery. This species has a close relative in Queensland, Astrce petrosum, but it is more elevated than the Western
Australian form. A common north Aus tralia and south Pacific island Star shell (Astralium stellare) has a single row of well-developed spines on the periphery of the rather flat whorl. The opercula of Star shells are oval, solid and spiral.

\section{PHEASANT SHELLS}

The home of the Pheasant Shell is in Australia and the south Pacific islands. The rich and varied colouring and intricacy of pattern on the polished shells belonging to this genus outshine that of the pheasant, from which they receive their popular name. When alive the shells are found on weeds and blades of sea grass, but empty shells are frequently found washed up on sandy beaches.

The largest member of the family is the Australian Pheasant Shell (Phasianella australis) (Frontispiece, fig. 13). This species is found in the southern States of the Commonwealth, and reaches to a length of two to four inches. There is great variety of colouring in the species. and within the oval mouth can be seen the white china-like undersurface of the shell. The commonest species found, however, are much smaller than the Australian Pheasant Shell. In southern Australia generally occurs a small species about an inch or less in height. This species is Phasianella ventricosa (Frontispiece, fig. 14), is generally rosy pink, with lighter bands and darker markings, and has rather swollen whorls. The common small species of the south Pacific islands and north Australia is Phasianella variegata; in Western Australia occurs a very small, exquisitely marked species (Phasianella tomlini), and an extremely minute Pheasant shell (Phasianella virgo) from New South Wales is similar in size, but is more swollen and more common than a deep rose pink-species (Phasianella rosea), which is recorded from Victoria as well as New South Wales. 


\section{Ernest Wunderlich, F.R.A.S.}

$\mathrm{M}$

R. WUNDERLICH, a former Trustee and President, whose photograph is reproduced in this number, has been a generous patron of this Museum over a period of years; indeed, he has been our most munificent donor during the past quarter of a century. His gifts to the Museum include various archæological objects, originals and reproductions, from Egypt and elsewhere, among which may be specially mentioned a beautiful cast of the bust of Queen Nefertiti. ${ }^{1}$ The fine group of three aboriginal figures executed by Mr. Rayner Hoff was a gift from Mr. Wunderlich, who has also presented to the library of the institution a valuable series of publicatious, mainly on archxological subjects.

But perhaps his greatest service to the Museum was the origination of The Australian Museum Magazine. It was Mr. Wunderlich who proposed that a journal containing popular scientific articles, suitable for non-technical readers, should be issued by the Trustees, and it was mainly due to his enthusiasm and energy that the publication was launched. It was for some years the only journal of its kind in the Empire, and its influence in instructing the Australian public in the natural history of the continent and its surrounding seas, and in the work

\footnotetext{
${ }^{1}$ Australian Museum Magazine, IV, 1931, p. 270.
}

of the Museum generally, has been considerable.

Though no longer a Trustee, Mr. Wunderlich has always maintained a

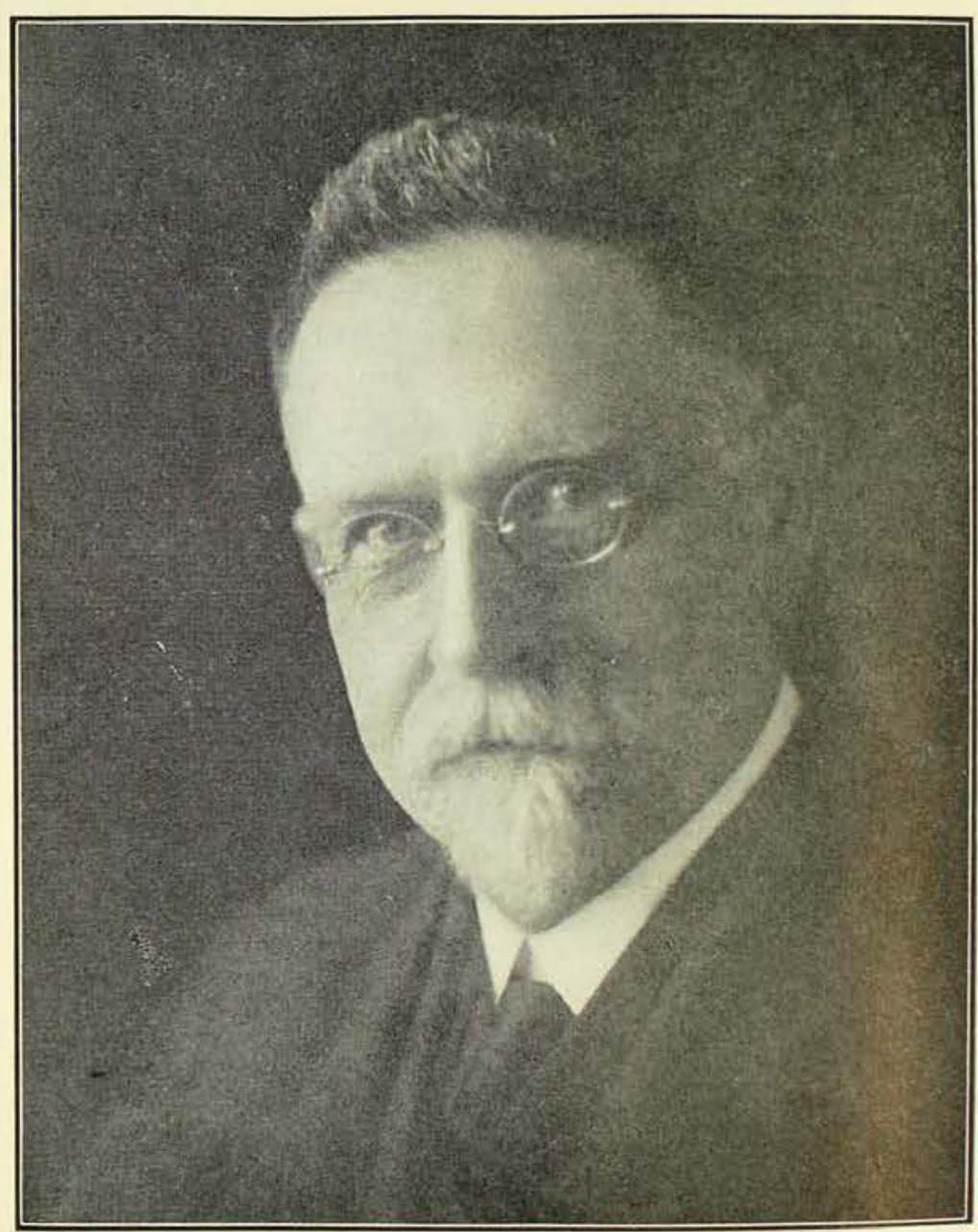

Ernest Wunderlich, F.R.A.s.

keen interest in the welfare of the Museum and the success of the Magazine, to the pages of which he has himself been a contributor. 


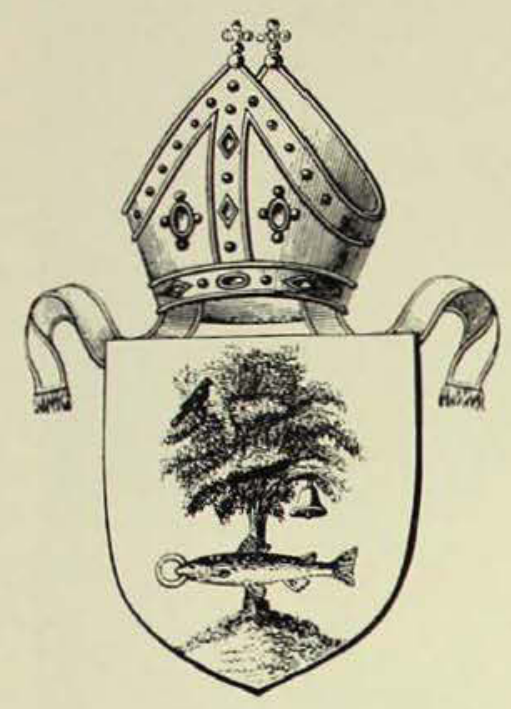

\title{
The Fish and the Ring
}

\author{
IN FABLE AND IN FACT
}

BY

G. P. Whithey.
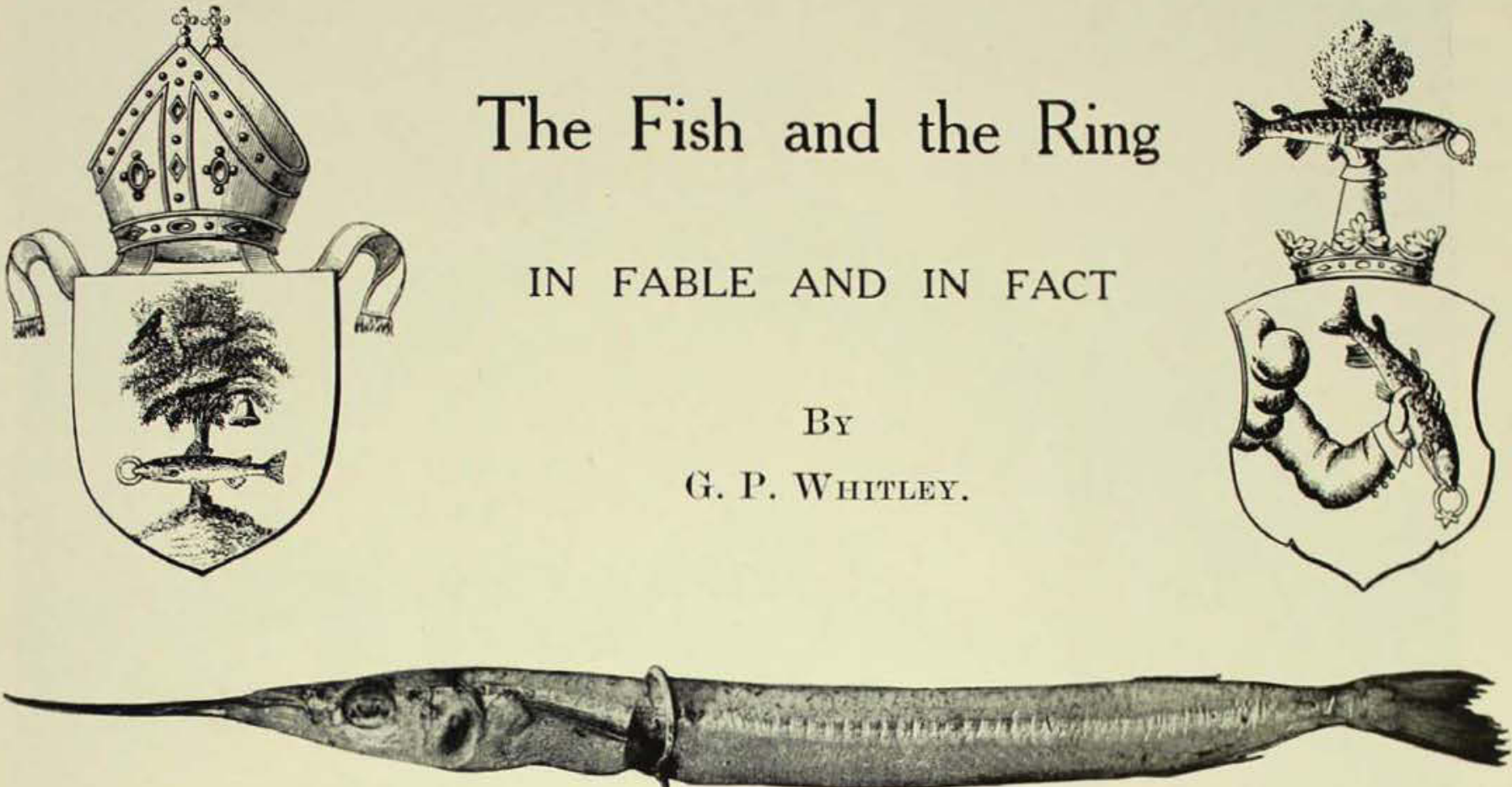

\begin{abstract}
A garfish from New South Wales encircled by a rubber ring which had adorned it for some time, as the groove on the fish shows.

To the left of the title appear the arms of Glasgow bearing a fish with a ring in its mouth; on the right, a similar device appears in the erest of an old Bavarian family.
\end{abstract}

$\mathrm{I}^{\mathrm{s}}$

August, 1934, the Fisheries Branch of the Chief Secretary's Department, Sydney, reported that a garfish had been caught near Port Stephens with a rubber ring round it, and asked me whether this was accidental, or if the ring had been placed there as a tag for tracing migration. The specimen was presented to the Museum, and its photograph now heads this article. It was a ten-inch Sea Garfish (Reporhamphus australis) from the fish markets, but its body was encircled by a small rubber ring which it had evidently worn for some time, as the ring had become white and a groove had been worn in the belly of the fish. Apparently rubber rings get into the sea from rubbish tipped over from barges, or washed to sea in stormwater, so the garfish may have become adorned with its unwelcome ornament in the neighbourhood of Sydney.

Curiously enough the phenomenon of ringed fishes is not uncommon in other countries, but this is the first case recorded from Australia. In Europe and
America mackerel and other fishes apparently nose about in the sea and thrust their snouts through the bands from lemonade bottles and other rubber rings which are amongst the rubbish dumped at sea. The bands are not put on by fishermen as a joke, as might be thought: indeed, it is difficult to make a fish wear a band, and experiments I have attempted by placing rubber bands in the sea where mullet, garfish, and other species are common, have been quite fruitless so far.

One of the queerest cases overseas was that of a swordfish (Xiphias gladius) landed at Boston, U.S.A., in the summer of 1926 , which had a rubber band round its sword, around which it had worn quite a groove.

Near Habana, Cuba, a shark was noticed behaving strangely, when it was found to have nose-dived into an old automobile tyre and become encircled thereby.

For about half a century reports have been current in America of mackerel (Scomber) being caught almost yearly 


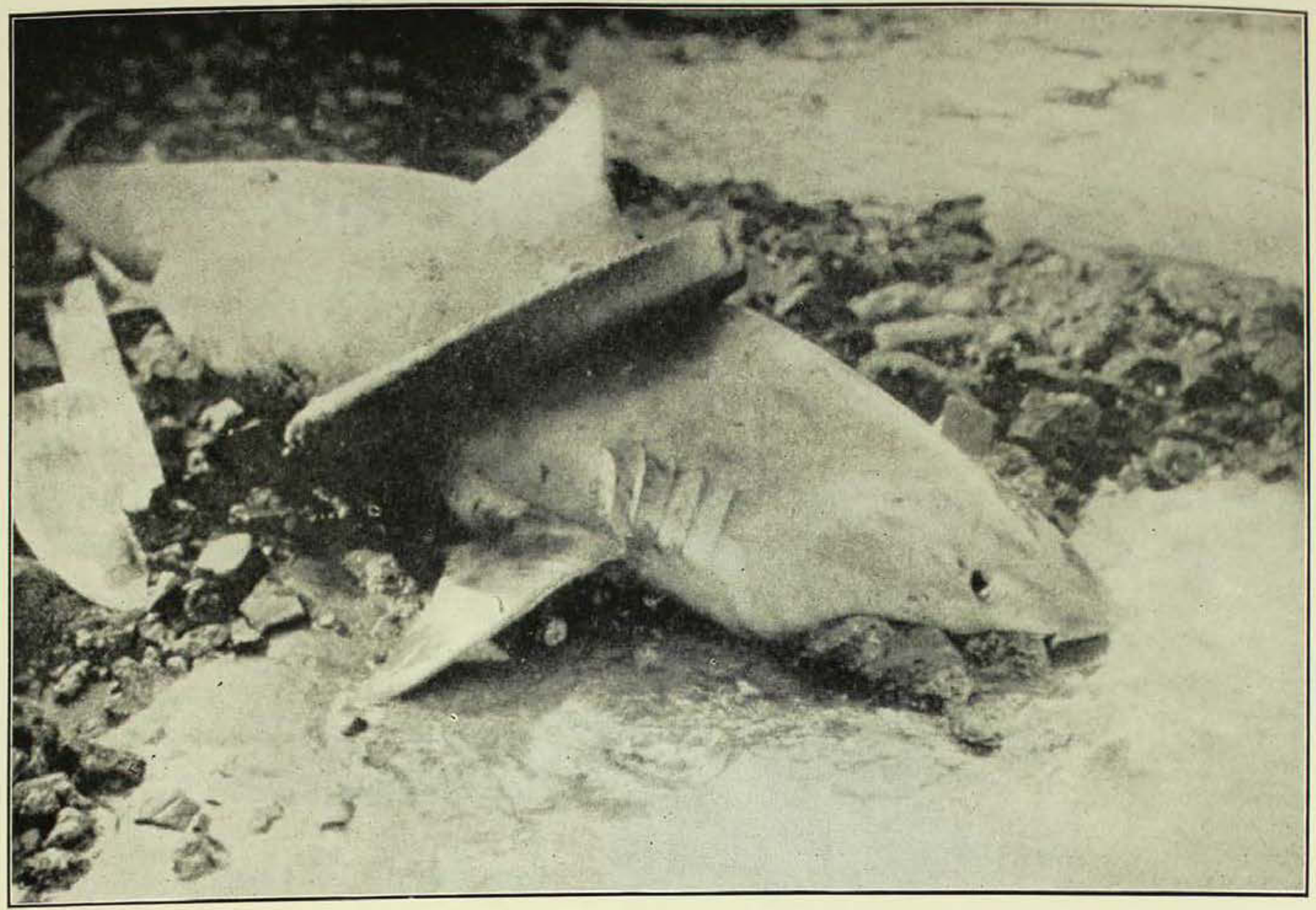

A shark encircled by an automobile tyre, eaptured at Habana, Cuba.

[After Diario de la Marina, Habana.

with rubber bands round their bodies, and the records have been collated by Dr. E. W. Gudger of the American Museum of Natural History. Similar reports come from Great Britain, France, Germany, and Sweden. In one case Dr. Gudger discovered a mackerel which had so outgrown its rubber ring that the flesh had re-formed over the belly-groove, so that the ring was finally threaded or rove through the body of the fish.

Recently Dr. Fernando de Buen, of Madrid, sent me an article ${ }^{1}$ of his on the presence of rubber rings on Needle Fishes (Rhamphistoma), a genus rather like our Long Toms and garfishes. Dr. de Buen records that some 350 or 400 needle fishes, encircled by rubber bands, were netted in the Mediterranean Sea. He assumed that shoals of needle fishes, in passing places where rubber rings had been thrown into the sea, might attack them and pass their

${ }^{1}$ For a translation of this article from Spanish
into English, I am indebted to my German teacher, into English, I
Mr. F. C. Rose. sharply-pointed heads through them. With specimens of large size the head remained imprisoned in the foreign body, the eyes thus being covered; with others of smaller size the ring was found on the fleshy parts of the body, whilst in very young fry the foreign body was posterior to the ventral fins.

It seems likely, therefore, that further ringed fishes may come to light in Australian waters. If so, I should very much like to hear of them or obtain actual specimens.

In searching the records of ringed fishes, I recalled several legends of "the fish and the ring" dating from the days before rubber rings were invented. Whilst the cases we have dealt with have been those in which the ring encircles the fish, the reverse often obtains in the legends, the fish swallowing the ring. Some of these stories are quaint and are worth consideration here as they do not appear to have been associated hitherto with the mythology of long ago, the heraldry of 
the Middle Ages, and the modern examples of ringed fishes.

"The legend of the fish and the ring", says Dibdin," "is extant in well nigh every chap-book in Scotland; old Spotswood is among the earliest historians who garnished up the dish from the Latin monastic legends. . . ." He then recalls the report of St. Kentigern [or St. Mungo, as he is also called], that a lady having lost her ring in the River Clyde, and her husband waxing jealous, she consulted St. Kentigern, entreating his help for the safety of her honour. The saint told a fisherman to bring him his first fish
King Solomon once entrusted a valuable ring to Amina, one of his numerous wives. A demon named Sakhar assumed the form of Solomon, got possession of the ring, and sat on the throne as king. Solomon became a beggar, but, at the end of forty days' usurpation, Sakhar fled, casting the ring into the sea. The ring was swallowed by a fish, which was later served to Solomon, who thereby established his identity and resumed his interrupted duties.

Polycrates, prior to his death in 522 B.c., had been the luckiest man alive, and a similar tale was woven around him.

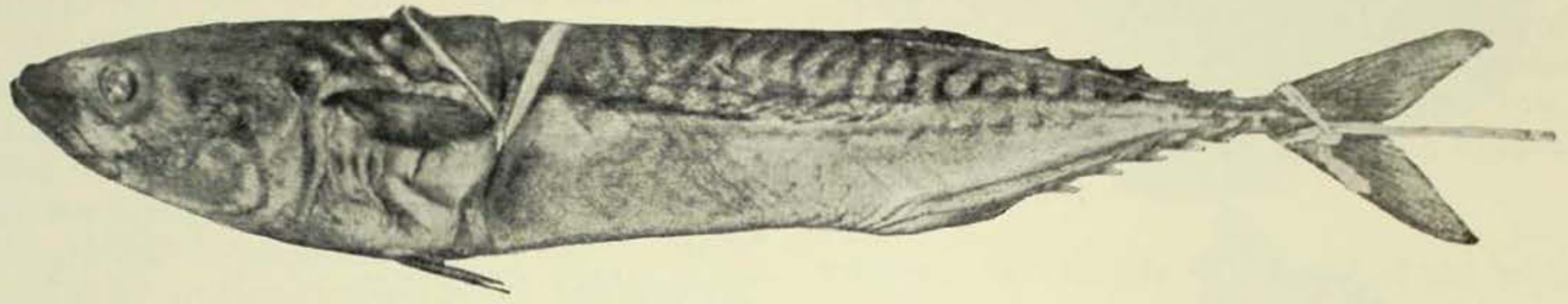

A mackerel with a rubber ring passing right through its body. A mark where the band has chafed the fish appears to the right of the rin.

[After E. W. Gudger.

caught. In the mouth of this fish the ring was found, and the lady was freed of her husband's suspicion. The see and city of Glasgow, the scene of the saint's labours (A.D. 514-601), "do both of them bear in their arms a fish with a ring in its mouth even to this day".

This was no new story, however, as a similar legend crops up in several countries throughout the centuries. Theseus is said to have proved his parentage by a like miracle, about 1250 B.C.

In a Sanskrit drama called Shakuntala, written in the fifth century, the story is told of King Dushyanta, who, probably before 1000 B.c., gave his humble wife, Shakuntala, a ring which she lost while bathing. A fish swallowed the ring, was caught and taken to the king, who rehabilitated his wife, whom he had meantime forgotten and even denied. ${ }^{2}$

\footnotetext{
${ }^{1}$ Quoted in Moule's The Heraldry of Fish, 1842, p. 125 .

"Mackenzie, Indian Myth and Legend, 1916 ,

p. 163 .
}

Polycrates was so proverbially fortunate that it was suggested that he throw away the thing he valued most. He cast an engraved emerald ring into the sea, but a few days afterwards a fish was served at his table, and in it was this very gem. Schiller composed a poem about this incident, Der Ring des Polykrates, of which this is one verse:

But when the cook his knife applied,

In loud astonishment he cried,

And ran the marvel to disclose.

"The ring, Sire, which thou used to wear I found in yonder fish: 'tis here,

Truly, thy luck no limit knows."

Such a man would have no difficulty in winning lotteries nowadays.

Further tales of the fish and the ring are told about "the cruel Knight and fortunate Farmer's daughter", said to be Sir Thomas Elton and Dame Rebecca Berry. The story appears in the Talmud and the Arabian Nights, and, as we have seen, also concerned St. Kentigern. In the various Lives of the Saints there are half a dozen like tales of lost cathedral 
keys, episcopal rings, and other objects retrieved by fishes. The Pope still seals his breves with his "fisher-ring", and every doge of Venice since Sebastiana Ziani (about A.D. 1172) has "married" the SeaGoddess by throwing a ring into the Adriatic on Ascension Day.

There must be some reason for such a curious story occurring in the legends of Arabia, Greece, England, Scotland, Germany, Hungary, Russia, Scandinavia, India, and the Holy Land for so many centuries. It cannot be due to mere coincidence.

It has been suggested that the ring represents the annular currency which formed the money of olden times. In the Eddas of the twelfth century, the Pike or Luce (Esox lucius) or else a dwarf in the form of a pike, is the guardian of gold and
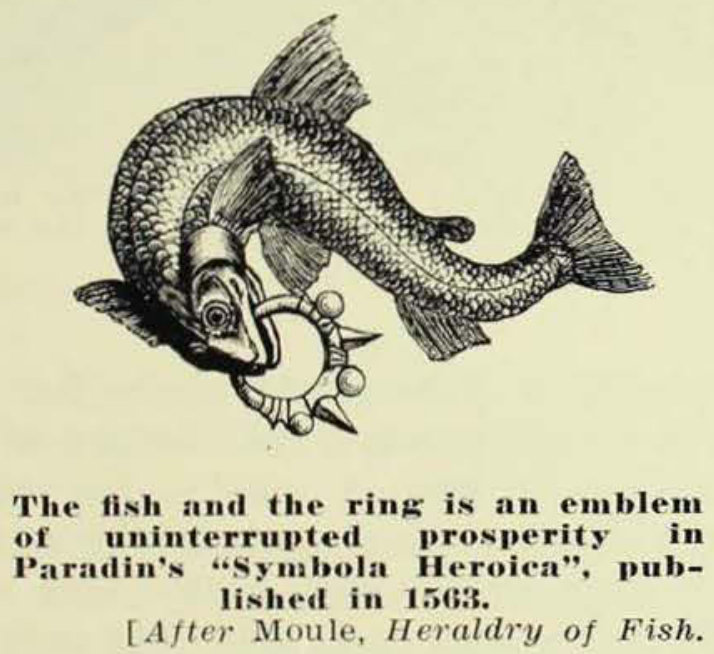

of a ring which, if lost or stolen, brings great disaster. Thus we can perhaps thank the fish and the ring legend for having indirectly inspired the mighty music of Wagner's Ring of the Nibelungen, a modern allegory of the tale, occurring in the sagas, of the Rhine Gold stolen by the dwarf Alberic and yielded to Loki and the gods.

Ingenious as the annular money theory is, and comparable with the tribute yielded by a fish in Matthew xvii, 27, we must apparently delve still deeper into the past for the solution of the fishring story.

The real origin of the legend, so far as can be traced, is revealed by the researches of that remarkable linguist,
Professor Gubernatis, who, in his Zoological Mythology, traces it to Aryan sources. The story has of course been altered or corrupted in various countries since the remote times, two or three thousand years B.c., when the Aryans dispersed, but the primary essence seems to be this: the ancients believed that when the sun set behind the horizon of sea or river, it was swallowed by a fish or seamonster, which brought it forth the next day.

In a Russian poem, Kaniok Garbunok, quoted by Gubernatis, "Ivan must seek, for the sultan, a ring shut up in a casket which has fallen into the sea (the evening or autumnal sun). Ivan . . . arrives in the middle of the sea, where there is a whale which cannot move because it has swallowed a fleet, that is to say, the solar vessel. . . ." Gubernatis compares this with the sea-monster swallowing Hanumant in Râmâyanam to vomit him forth again, and with the biblical Jonah: I would also add the similar account given by Baron Münchhausen.

In its various forms the legend tells sometimes of the solar hero or heroine who takes the form of a fish to save himself or herself, or a fish helps the sunperson to escape. Sometimes a golden or luminous fish plunges to seek the pearl, ring, or key for the hero or heroine who had lost it. Or a fish vomits forth from mouth or tail the hero, pearl, ring, or other symbol of the solar disc, which it had swallowed. "Out of the cloudy, nocturnal, or wintry ocean, comes forth the sun, the pearl [or ring] lost in the sea, which the gold or silver fish brings out"; that seems the basis of all the later stories of the fish and the ring.

Somebody recently lost a valuable ring in the surf near sydney, and a reward was offered. So far no obliging fish has come to light with the ring in its mouth, but I am still hoping that past unnatural history may repeat itself for my benefit, and that is why I am examining every fish from the locality. 


\section{The Adventures}

\section{of a \\ Tobacco Tin}

$\mathrm{BY}$

T.' HoDge-SMITH.

$\mathrm{H}^{\prime \prime}$

OW many of us have carelessly and without a single thought thrown overboard an empty tin? Maybe it originally contained tobacco or chocolates. If we ever did cogitate on the ultimate fate of the tin, what would our conclusions be? Well, this is a true story of a tobacco tin thrown into the Bonville Creek, below Coff's Harbour, some years ago by a man whose name is not known. The erstwhile owner, the greatest and most wonderful product of evolution, is forgotten, while the useless discarded tin now becomes famous by telling an amazing story of Nature's treatment of it. Let the tin tell its own story.

My supply of tobacco was rapidly diminishing and finally I was taken from a comfortable coat pocket by my owner. Carefully shaking every piece of tobacco out of me, he cast me into the river without even closing down my lid. This was a most unfortunate omission on his part, for on hitting the icy cold water I was unable to keep my balance on the rough surface of the river and toppled over; rapidly filling with water, I sank immediately, coming to rest on a sandy bottom, and seemed to stay in that wet gloomy place for ages without anything happening at all. Of course the water was continually flowing past me at not an unpleasant rate. Then came a time when my peaceful life was rudely inter-

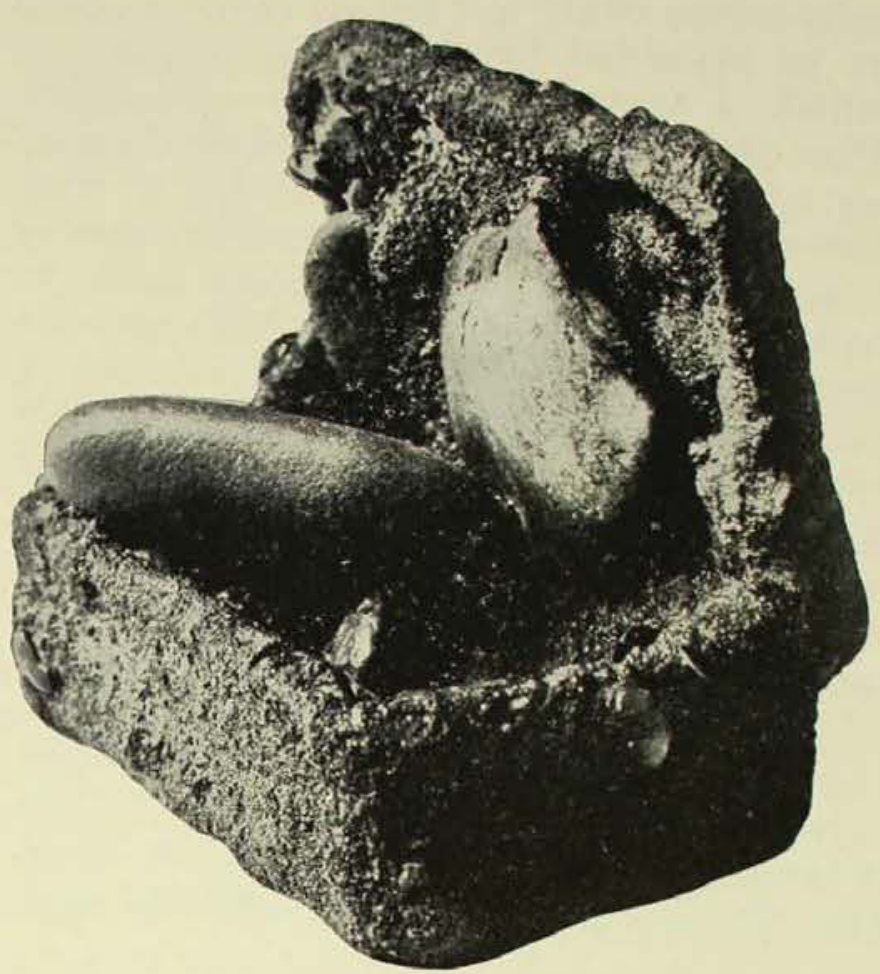

rupted. Gradually the speed of the water became greater, and with this its muddiness increased until I could no longer retain my position and I started off downstream. At first this was a welcome change, but soon I was enveloped in coarse sand, pebbles and even large boulders. Quite suddenly something happened, I know not what, but I found myself buried in wet sand and pebbles. While I do not know what actually happened to drag me from my more or less pleasant surroundings to this dark dungeon, I rather suspect that storms, accompanied by heavy rain, brought large quantities of water into the river. The resulting flooding of the river enormously increased its speed, and this meant that it was able to tear up mud, sand and even boulders and transport them for considerable distances before the volume of water decreased and lessened in speed. As soon as the river got back to anything like normal I was unceremoniously dumped down and buried with the rest of the debris. During my enforced imprisonment an insidious disease seemed to attack me, first along my edges, but gradually spreading through my whole system. Tiny molecules of oxygen and hydroxyl, so small that the most powerful 
microscope could not detect them, seemed to be attracted by the atoms of iron of which I was almost wholly composed. This attraction resulted in the union of my atoms with these strangers, I soon lost my bright appearance and gradually I became totally changed from iron to rust. This was not the only change, for some of the united molecules formed a jelly-like substance and began to wander away from me. The passage was greatly impeded by the presence of so much sand and pebbles so that they did not get very far. The jelly substance then set hard and held the sand grains and even the pebbles to me. So began a process that would end by finally converting me into ferruginous sandstone. However, another of those dreadful storms saved me from this. The fast flowing river, slashing and cutting everywhere, removed all the sand and pebbles that had rested on me for so long, carried me away and dumped me on the shore near Sawtell. I had not been long there when Mr. A. H. Jackson picked me up. He seemed to be attracted to me and certainly spent a considerable time in admiring me. He showed me proudly to other people, and finally sent me off to the Museum, where they greatly fussed over me, and even took my photo. Oh, well! Now that I am really famous perhaps I can forgive those straying atoms of mine and forget all about my long imprisonment. By the by, I heard the Museum men debating just how old I was. Well, I really cannot help them because I do not know myself, but I do know that they did not have radio when I was a bright young thing.

\title{
Hawk Moths
}

\author{
By Naxcy B. Adams.
}

$\mathrm{T}^{\mathrm{T}}$

HESE swift-flying moths may be seen at dusk darting from one strongly scented white flower to another, pausing at each one to rob it of its store of honey. They belong to the family Sphingidæ, the members of which are remarkable for their swift and powerful flight.

\section{LIFE HISTORY.}

The eggs are laid on the particular food plant favoured by each species, and when the caterpillar emerges from the egg it commences to feed on the leaves. These creatures are sometimes known as Sphinx Moths, a name suggested by the curious attitude assumed by the larva when disturbed. The fore part of the caterpillar is raised at right angles to the rest of the body, and the head is inclined forward; this extraordinary position may be maintained for hours. When full grown the caterpillar crawls away to find shelter among fallen leaves, where it pupates. As a rule it makes a covering for itself of coarse threads of silk and damp leaves before pupating, or it may form a cell deep under the soil. The pupal stage is a quiescent period, during which the caterpillar changes into a moth, which eventually splits its pupal shell and flies away. These moths have all the characteristics of swiftness of flight-smoothcoated, compact, cleanly tapering bodies, long narrow forewings and small hindwings. They are essentially a tropical family, but nevertheless are found in varying numbers practically all over the world. They are particularly numerous on the Island of Barbadoes in the West Indies, an interesting fact mentioned by H. M. Lefroy in his book, Indian Insect Life. Lefroy states that: "This island is low and wind-swept, less than 20 miles across, and any but a strong flying moth is liable to be blown away by the Trade Winds, just as large numbers of insects are sometimes blown on to the island; 
apparently the Hawk Moths have been able to remain on the island, and they constitute an extraordinarily large proportion of the insect fauna."

Hawk Moths play an important part in the pollination of flowers. Many of them have exceptionally long sucking trunks which are carried coiled up beneath the head. This trunk can be uncurled rapidly and inserted into a flower to reach the nectar on which the moths feed. In Madagascar there grows an orchid with a nectary tube eleven inches long, which reserves its store of honey for a Hawk Moth with a proboscis of the same phenomenal length. In Australia these creatures visit slender tubular blooms such as the Honeysuckle. The white masses of this strongly scented flower are visible long after the bright colours of other flowers have vanished in the approaching dusk. The pollen-laden stamens of the freshly opened Honeysuckle stand out conspicuously, and when thrusting its proboscis into the nectary tube the moth becomes thickly dusted with pollen grains. It may then fly to an older blossom whose withering stamens droop downwards while the pistil has lengthened so that the stigma is almost certain to become coated with pollen as the moth brushes past. This co-operation between insects and flowers for their mutual benefit is one of the most absorbing subjects of natural history.

\section{THE DEATH'S HEAD MOTH.}

A particularly well known member of this family is the Death's Head Moth (Acherontia atropos), a European species which does not occur in Australia. The appearance of this moth has given rise to all manner of curious superstitions. In olden days it was regarded as the messenger of pestilence and death because it is marked with a white skull on its back. This moth is a marauder of the honey stored by the bees in their hives. When disturbed or frightened, it utters a mournful cry, which is supposed by some naturalists to resemble the voice of the queen bee and to strike the inhabitants of the hive motionless, so that it carries

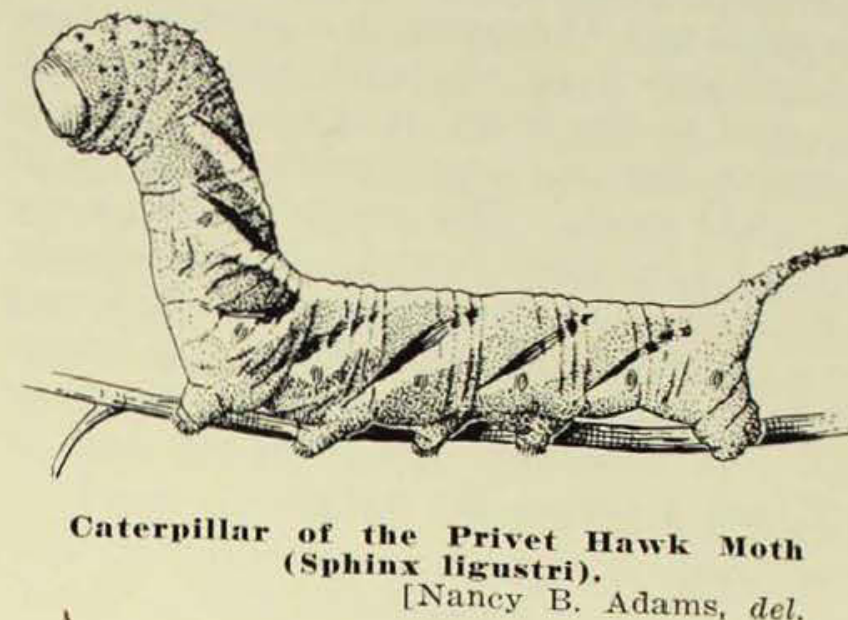

on its ravages unharmed. This plaintive cry has added to the superstitious dread produced by the symbol of death upon its back. The bees sometimes barricade the entrance to their hive with a thick wall made of wax and propolis to prevent the entry of this intruder. The wall contains one or two tiny openings to allow the bees to pass in and out.

The Privet Hawk Moth (Sphinx ligustri), has an extensive range, and is quite common in sydney. The large pale green caterpillars, which are marked with seven white stripes on each side and adorned with an upstanding horn at the posterior end, are often found towards the end of summer on privet hedges. This caterpillar is an excellent example of protective coloration. When isolated from its natural setting the insect is a striking and conspicuous object, but when in its customary surroundings, among the leaves of privet and other garden shrubs, it is extraordinarily difficult to detect.

Another cosmopolitan species is the Convolvulus Hawk Moth (Herse convolvuli), which is found even in New Zealand, where it is the sole representative of the family. The caterpillars are large and stout, measuring up to three and a half inches, and armed with a fleshy horn at the posterior end. They are extremely variable in colour, though usually green with black and white markings. The larvæ feed on the leaves of convolvulus, and occasionally occur as a serious pest of sweet potatoes, stripping the plants of foliage. When fully fed, the caterpillars bury themselves in the 
soil and pupate about two inches below the surface. The pupa is a curious dark reddish-brown object, with a long trunk attached to the front of the head; this is a sheath for the long sucking tongue of the adult moth. The moth is dark grey mottled with deep brown. The abdomen is marked down the centre with a broad brown stripe, and has short transverse bands of white, pink, and black on either side. It measures about three and a half inches across the wings.

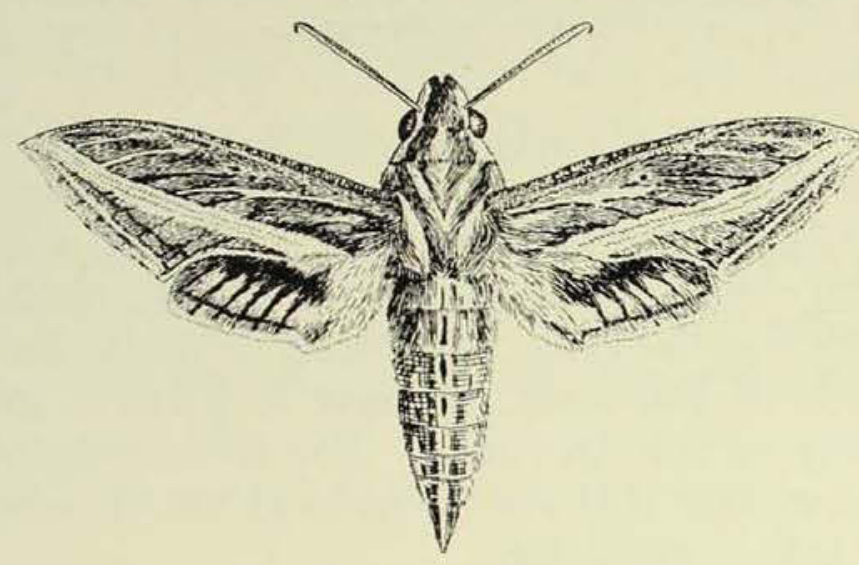

The Silver Striped Vine Moth (Hippotion celerio).

[Nancy B. Adams, del.

Hippotion celerio, sometimes known as the Silver Striped Vine Moth, is a European species that is common in Australia. The caterpillars, which vary in colour from green to brown, and are marked with eye spots on the hind segments, are extremely voracious, and occasionally are found on vines which they strip of leaves in a single night. The brownish pupa are concealed among the fallen leaves below the vine, or just beneath the soil. The moths themselves are greyish-fawn with three silvery-white lines forming a diagonal stripe across the forewings; the hindwings are bright pink and black, and the body is marked with silver spots.

Hippotion scrofa, a smaller species than the former, is a pretty little brown moth with bright orange-red hindwings narrowly edged with dark brown. It is widely distributed along the east coast of Australia, the brown caterpillars being often found feeding on grass.

The most striking Australian member of the family is Cœquosa triangularis, a

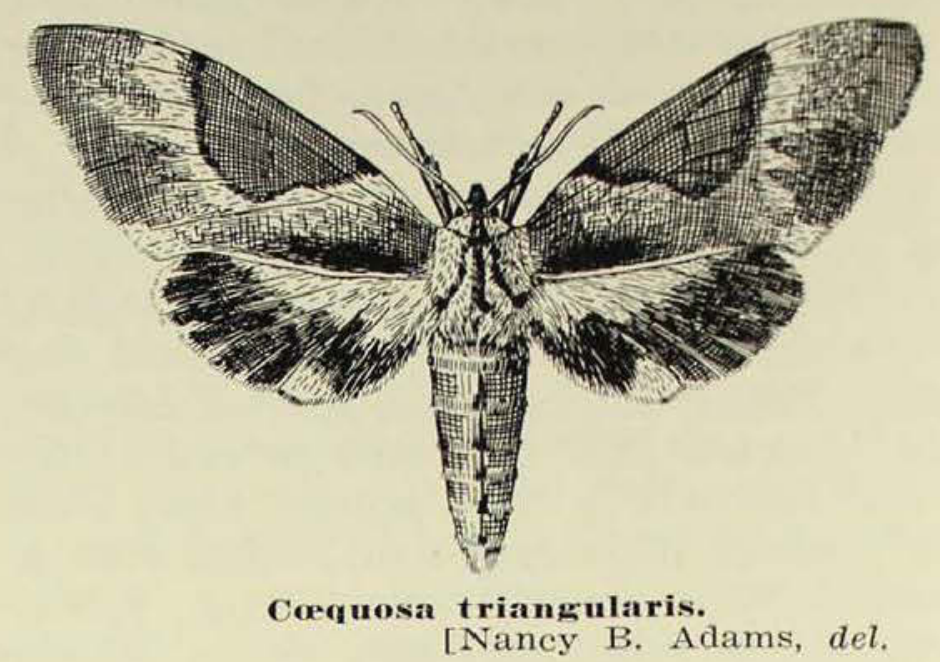

species with a remarkable larva popularly known as the Double Headed Caterpillar. It is a large obese creature with a rough granulated skin, pale green with variable yellowish markings. The head is small, and at the posterior end is a pair of swollen processes used for clinging to the food plant. Above these on either side is a black, shining, eye-like object, which gives the caterpillar the appearance of having a second head. If touched, the larva lashes from side to side as though trying to strike. It feeds on the leaves of Banksia and Persoonia, and when full

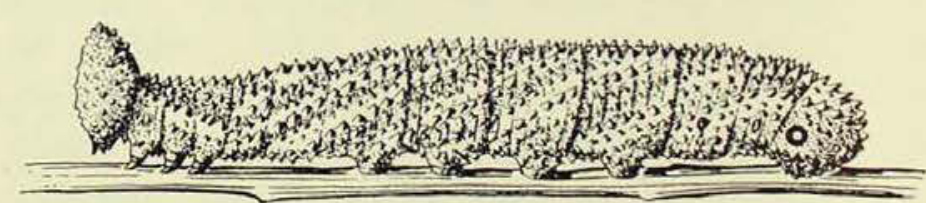

Larva of Coequosa triangularis-the Double-headed Caterpillar.

[Nancy B. Adams, del.

grown pupates on the surface of the ground in a nest formed of dead leaves jointed together by a coarse web. The pupal case is shining black, with reddishbrown segmental divisions. The moths emerge during January and February. They are very beautiful velvety brown and orange creatures, the forewings each being marked with a deep brown triangular patch. These moths may measure six or even seven inches across the outspread wings.

Although the majority of Hawk Moths are nocturnal, a few are day-flying insects. Of these, Cephonodes hylas is the only 


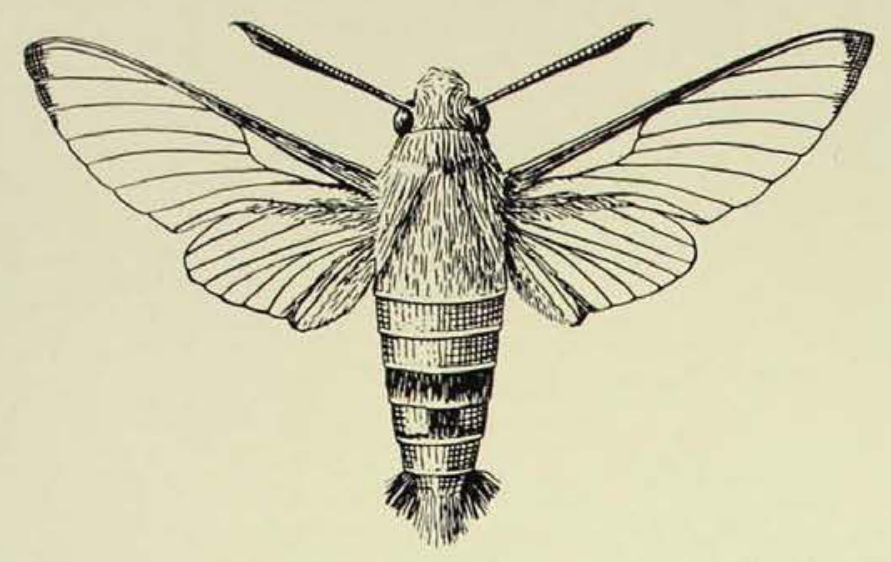

The Bee Hawk Moth (Cephonodes hylas). [Naney B. Adams, del. one that is at all common in Australia. Its body is olive green, the abdomen yellow with a broad black band across the middle, and at the posterior end is a large tuft of soft black bristles forming a bushy tail. The wings, except for a very narrow outer edge of olive green scales, are clear and transparent the supporting veins showing as slender black lines. It is a small species, measuring about two inches across the wings.

These day-flying species bear a remarkable resemblance to bees and wasps, often being called Bee Hawks.

\section{Notes and News}

Major Allan Brooks, of British Columbia, who is regarded by many as the foremost bird artist of North America, visited the Museum in February last, and was greatly interested in the exhibits and enthusiastic in his praise of the methods of taxidermy. These, he said, were faithful and artistic, and the technique compared very favourably with that of the older world.

Another visitor who found the collection equally praiseworthy was Dr. R. L. Sutton, Professor of Dermatology in the University of Kansas. Professor Sutton is a noted big-game hunter and fisherman, who has travelled widely in pursuit of sport.

On Monday, February 4, about 250 world tourists from the R.M.S. Franconia, Cunard Line, visited the Museum, and were conducted round the galleries. They showed great interest in the Australian fauna and the Australian and Pacific islands ethnographic collection.

On Saturday, February 2, Dr. F. P. Keppel, President of the Board of Trustees, Carnegie Corporation, New York, called at the Museum and discussed with Dr. Anderson, Director, the special needs of the Australian Museum and the general question of grants by the corporation in aid of the educational work of Australian museums and art galleries.

Other recent visitors included $\mathrm{Mr}$. Norman B. Tindale, South Australian Museum, Adelaide; Mr. W. H. M. Andrews, Norfolk, England; Mr. W. H. Sargent, East London, South Afriea; $\mathrm{Mr}$. E. H. Chapple, Honorary Staff, National Museum, Melbourne; Miss J. H. Robertson, formerly of the Geological Survey of Tanganyika Territory. 


\section{Caloundra: A Naturalists' El Dorado by Albert E.J. Thackway.}

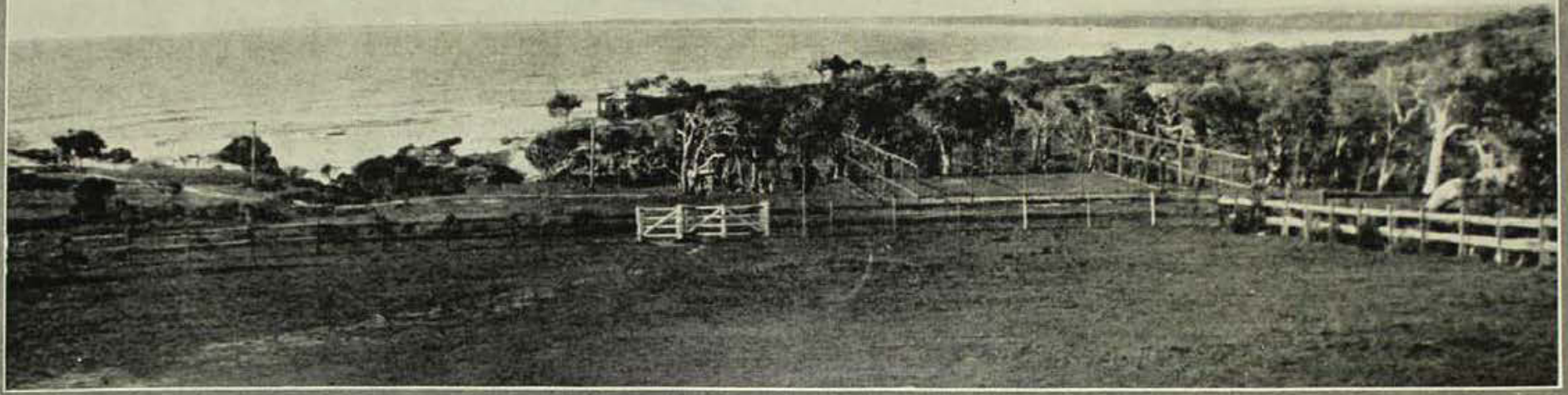

A general view of Caloundra.

$\Lambda \mathrm{S}$ a collecting ground and investigation area for marine zoologists, professional and amateur, Caloundra, south Queensland, has attained a degree of enviable fame probably unsurpassed by any other similar coastal district in those parts of Australia which have been systematically explored by earnest students of maritime natural history.

The township itself faces the northern extremity of Bribie Island, which, in turn, is situated at the north end of Moreton Bay. It is some sixty miles or so north of Brisbane, and approximately two hundred and seventy miles south of Lady Elliott Island, the southern extremity of the Great Barrier Reef. It is somewhat off the beaten track, but is, nevertheless, easy of access. A good motor road takes one right into the township. Those who are not so fortunate as to possess a motor car can reach Caloundra by taking the train from Brisbane Central Railway Station and detraining at Landsborough. From this point one travels by service car for about fourteen miles.

The place is an ideal locality for a pleasure holiday or for scientific research. Whatever "ology" a student of nature may be interested in he will find at hand a wealth of appropriate material sufficient to appease the scientific appetite of the most ardent worker.

The collector of sea weeds will find ample scope for his activities, the several beaches at times being covered with a multitude of specimens of various genera and species. By just casually picking up odds and ends during a short walk along Dicky Beach one afternoon during October, 1934, thirty-three species of algæ were obtained in less than an hour.

In the preface to a technical paper dealing with some new species of mollusea from Caloundra, ${ }^{1} \mathrm{Mr}$. T. Iredale, the Australian Museum conchologist, referred to the district as being the "Eldorado of the shell collector". This expression is not an exaggeration. In his paper $\mathrm{Mr}$. Iredale states in another place, in describing a new species of helmet shell (Nannocassis torva) that the molluse in question "makes the eleventh species of Cassid found on the beach at Caloundra, a number probably unsurpassed on any other beach in the world".

1 "Caloundra Shells", by Tom Iredale, Aust. Zool., Vol. iv, page 331 et seq.. May 18, 1927. 


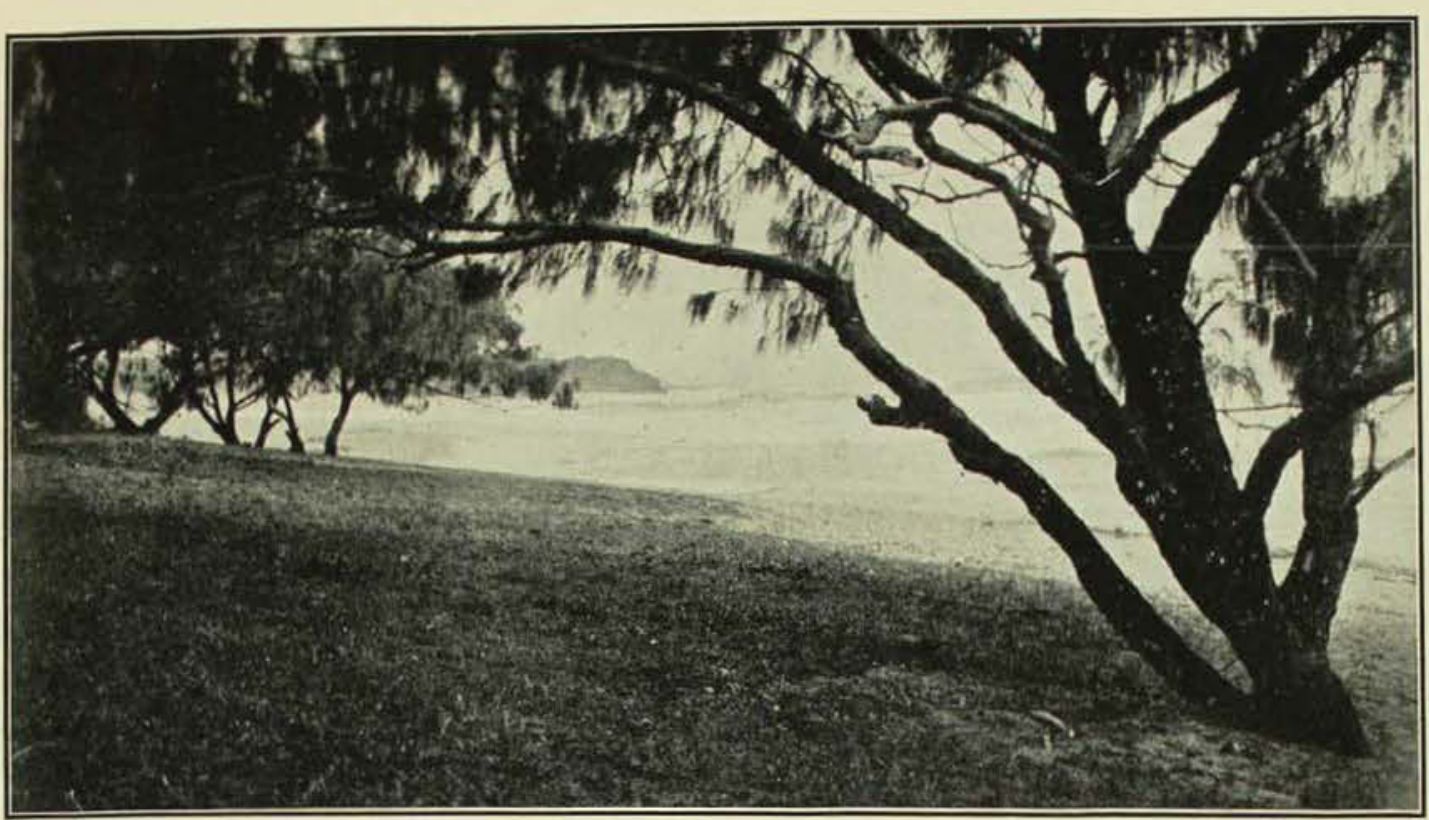

Shelly Beach, Caloundra. Mofrat Head in the distance. [Photo.-A. E. J. Thackway.

sponges, sea shells, corals and a host of other wonderful a $\mathrm{n} \mathrm{d}$ interesting marine life. But, of course, the beautiful and picturesque coral pools of the Great Barrier Reef are missing, and the colouring of the marine life generally, beautiful as it is, is not on such a magnificent scale as obtains on the Reef.

The surrounding scenery is wonder-

Nearly four hundred different species, comprising many thousands of almost perfect specimens of sea shells, were collected by the writer in ten days, and amongst the abundance of material gathered were not a few rarities. Twentytwo species of cowries (Cypræidæ) were secured from one spot, only a few yards square, near the southern end of Dicky Beach, during two afternoon collections. At another location near the foot of Caloundra Head, eight species of cones (Conidæ), twelve species of mitras (Mitrida) a $\mathrm{nd}$ large quantities of many other genera were gathered in a very short while, and this without intensive searching or wading into deep water!

The numerous rock pools reveal anemones of all colours, sea urchins, gorgeous marine worms, bêche-de-mer, sea snakes, crustaceans of every hue and shape,

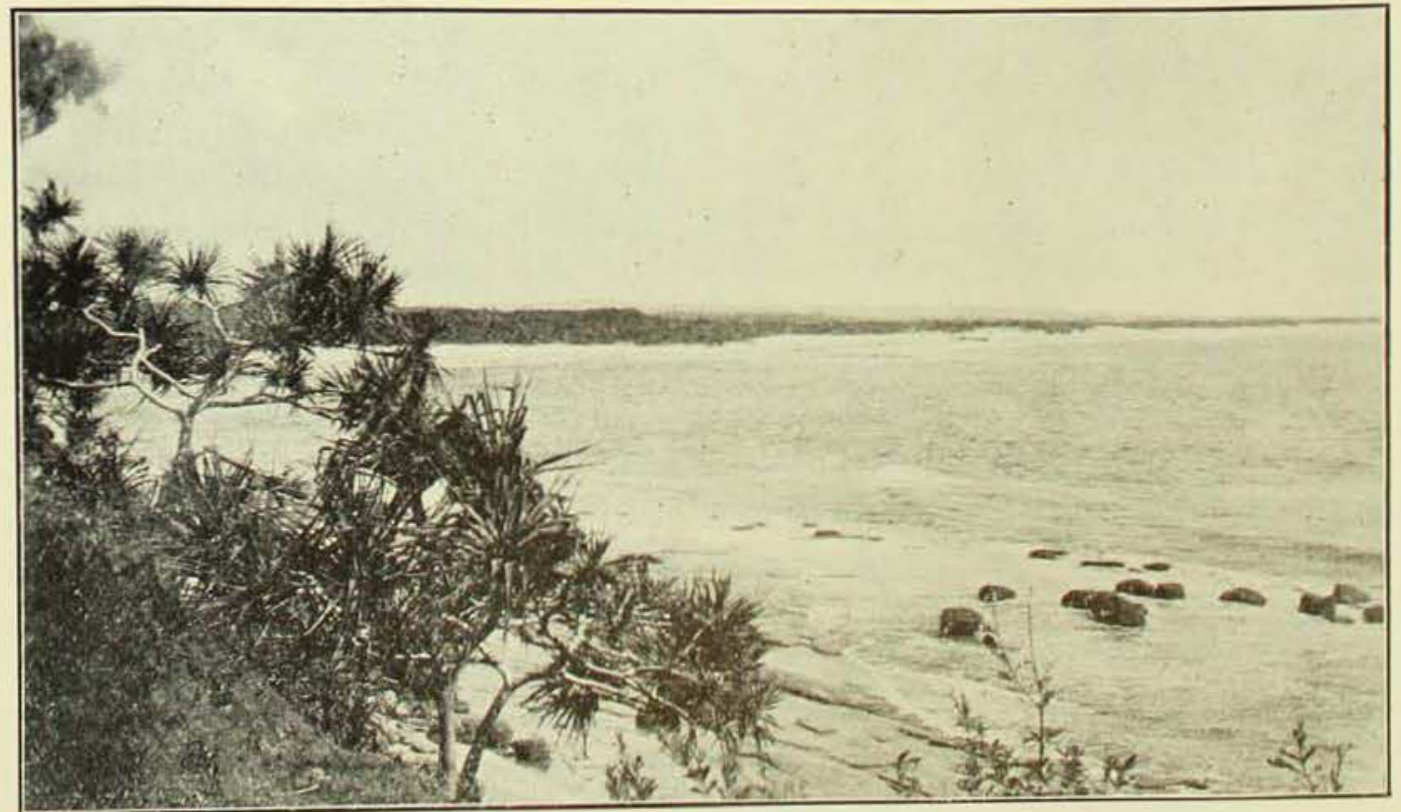

Dicky Beach, Caloundra, from Mofrat Head. The riehest collecting ground in the district is between the foreground and the small spit seen in the mid-distance.

[Photo.-A. E. J. Thackway. 
peaks reminded him of the glass houses or furnaces near his Yorkshire home). Looking north, the coastal line to Alexander Head is discernible on a clear day. The beaches appear to be ideal for surf bathing, and for the collector almost every marine condition from open sandy beach to enclosed lagoon and from rocky headland to stagnant backwater obtains.

Around Caloundra Head the rocky base projecting into the sea, and which is submerged at high tide, has large areas of smooth and comparatively level surfaces broken only by natural shallow channels, a few inches deep, which drain the tabletop surfaces. These areas are very barren and contain a number of peculiar rock pools. These pools are different from the usual type of irregularly formed rock pools usually seen on the sea shores and containing more or less marine life, in that they consist of holes practically cylindrical in shape. Although formed by natural agencies, they have the appearance of having been cut in the rock by the hand of man, so smooth and true are the walls and bottoms. The holes vary in size from diameters of about two feet to five feet, with depths of from about eighteen inches to six feet. The shape is almost invariably circular, with practically straight vertical walls or sides. In contrast to the other pools in the near vicinity, these cylindrical holes have a pronounced paucity of apparent life; in fact, the contents, other than the sea water, mainly consist of worn pebbles and a few fragments of broken sea shells resting on the bottom. The contrast to the otherwise exceptionally rich fauna of the district is most remarkable.

The palms (Pandanus pedunculatus) and the beach oaks (Casuarina equisetifolia) forming the dominant tree life along the open beaches, give a hint of coming tropical splendours which seem to have their genesis hereabouts. Many writers on marine zoology name this locality as the rough boundary between tropical conditions and the more or less subtropical nature of the country lying to the southward. That doyen of Aus- tralian conchologists, the late Charles Hedley, suggested the division of the Australian coast line, for scientific purposes, into a number of zones, each zone having its limits defined in accordance with its own peculiar fauna and flora, and in this connection placed the neighbourhood of Caloundra (to be precise, Noosa Heads, about thirty miles to the north, was specified) as the approximate dividing line between what he named the Peronian and the Solanderian zones.

It is probably due to these conditions that the fauna is so abundant, southern forms reaching this latitude in their northward journeyings and tropical forms coming down south until the relatively colder waters are encountered.

There are four main beachesCaloundra, King, Shelly and Dicky, from south to north in that order. The latter was so named from the s.s. Dicky wrecked there on February 4, 1898. Although thirty-seven years have passed since then, a considerable portion of the remains of the wreck can still be seen on the beach. Will another thirty-seven years still see some portions of the skeleton, or will nature have completed her task ere then?

By some strange perversity of nature the most disappointing collecting ground from a conchological point of view was found to be Shelly Beach. Shells were few and far between. What there were consisted chiefly of beach worn single shells of bivalves (Pelecypoda), the principal forms being a cream and white cockle (Cardium multispinosum), the fisherman's pipi (Donax deltoides) common to the New South Wales littoral and a few arks (Anadara nicholsoni). Practically nothing of value was seen. Shells common elsewhere were relatively rare here. Either the molluscan population has moved to a more desirable neighbourhood, or the person responsible for naming the beach was gifted with a subtle wit. The beach was anything but shelly in the sense that sea shells constituted its chief characteristic. It appeared to be the home of an interesting species of sand coloured crab (Ocypoda ceratophthalma), difficult to see until 
some movement takes place. On sunny days its presence is betrayed only by its shadow, so exactly does the protective colouring blend with that of the beach sand. These crustaceans are known locally as Ghost Crabs.

The richest collecting ground is that portion of Dicky Beach situated between the northern side of Moffat Head and a rocky spit about half a mile farther north. This stretch of coast can be seen clearly in the accompanying photograph of Dicky Beach taken from Moffat Head. There is also a rich bed of shell debris about halfway around Caloundra Head. A morning or afternoon spent quietly searching at this spot, which is uncovered at from half to low tide, will reveal many unsuspected molluscan treasures.

From entomological, ornithological and botanical points of view the field was not investigated, owing to time available for study and collection being fully occupied on the marine zoological side. Casual superficial observations made at odd moments indicated, however, that the harvest for the terrestrial worker should be no less prolific than that available to the marine student.

Cursory inspections made in the adjacent bush when the state of the tides precluded work on the shores, gave the impression that a visit to the district by the Coleoptera specialist would be amply repaid and return a plenteous reward in material and experience. The ornithologist also should find ample scope for his activities, particularly in the vicinity of Pumice Stone Channel and Bribie Island, the apparent rendezvous of myriads of sea birds; and the fish enthusiast, whether he be an ichthyologist or a humble disciple of Izaak Walton, will find in the waters around Caloundra all that he could desire in the way of specimens, sport or food for the inner man.

\section{Review.}

Insect Wonders of Australia. By Keith C. McKeown. (Angus and Robertson, Ltd., Sydney, 1935.) Crown 8vo., pp. viii $+252,16$ plates. Price 6 s.

Insect Wonders of Australia, by Keith C. Mckeown, is a work that ably fulfills the purpose set down in the preface as a "nature book of a popular type". Many of the insects of Australia differ from those of other lands as distinctly as kangaroos differ from their mammals. Mr. Mckeown introduces the reader to such interesting beasties as the Pie Dish beetles of the inland, the hardshelled ground weevils, the fire beetle, the bull dog ant of ancient lineage, termites with a meridional tropism, weird creatures which appear like things in bad dreams, for example, the spiny leaf insect (Ectatosoma).

Delightful illustrations form an attractive feature of the book, especially those of Dr. A. J. Nicholson, a past master in the art of insect photography. Two of these deserve especial notice: (1) the shepherding of the larva of the Miletus butterfly by ants at night -a remarkable flashlight photo; (2) the hovering Nemestrine fly-a fine example of photographic art. Dealing with the guests of ants, the author quotes interesting observations by our late visitor, Dr. Wheeler, the great ant specialist, on the Hetærius beetle, a close relation of our wonderful genus Chlamydopsis.

In the butterflies, Dr. Waterhouse's observations on Miletus are given in some detail. Other chapter headings are "Ant Lions", "Carpenter Bees", "Saw-flies", "Fig-insects, with an Ancient History", "Bugong and Case Moths", "Gall-making 
Insects", "Life in the Trees", "Termites", "Grasshoppers and Locusts", with their confused nomenclature, further complicated by the schoolboys' inclusion of Cicadas under the latter name-each capable of expansion into a large book. In dealing with luminous insects, the suggestion as to the "mystery" of light production is scarcely admissible, since it was recently artificially produced at the University of Sydney. ${ }^{1}$

Instinct, intelligence and tropism are humorously expounded in the case of the mud-nest-building wasp, that regardless of interruptions and results carries out a routine series of operations, not wholly unlike certain humans of my experience.

A bird-killing mantis is recorded, as also the shocking habit of certain husband-devouring species (page 156, repeated on page 182). These morals are counterbalanced by the reverential mien observed alike by Theocritus and St. Francis. The author himself knew of children in New South Wales who believed that if they should be lost in the bush the mantis could point a way out.

${ }^{1}$ See also Blair, South London Entomological and Natural History Society Proceedings, 1914.
Under Insect Courtship we hear that "the feathered antennæe" of the male have been found to vibrate rapidly to the note of the female mosquito and to no other. The love calls and scents of moths and butterflies, with their astounding range and efficiency, are briefly referred to. The matrimonial troubles of the male water bug (Spherodema), compelled by his mate to nurse the babies, is humorously treated. Mr. Mckeown shows that even bugs have their romances and associations quite otherwise than those studied domestically, including the melodrama of the Assassin Bug. One learns also that while a butterfly makes only nine wing strokes per second, the mosquito registers up to six hundred. The book is rounded off by a chapter on aboriginal insect foods, and the fastidious non-naturalist is reproached by the evidence of Saville Kent, Dr. Basedow, Carl Lumholtz and Baldwin Spencer. The second of these goes so far as to compare the taste of the witchedy grub with that of scrambled eggs slightly sweetened.

Mr. Mckeown suggests many lines of interesting research, and his book should find a wide circle of readers.

H.J.C.
Mr. J. R. Kinghorn, C.M.Z.S., herpetologist and ornithologist of the Australian Museum, has recently had conferred upon him the Diploma of the Museums Association of Great Britain. Mr. Kinghorn is the first Australian worker to have received this honour.

It is gratifying to be able to announce that at the recent examinations of the
University of Sydney, Miss Elsie Bramell, B.A., and Mr. F. D. McCarthy, both of the Anthropology Department of this Museum, were amongst those who passed successfully. Miss Bramell qualified for the degree of M.A., with second-class honours in Anthropology, and Mr. McCarthy for the Diploma in Anthropology (Dipl. Anthr.), which has been gained only twice previously. 


\title{
Fishing in Tanga
}

\author{
By F. L. S. Bell, M.A., F.R.A.I.
}

$\mathrm{L}^{\mathrm{F}}$

EANING on the gunwale of a canoe drawn up on the white coral beach of Boieng Island, Tanga, ${ }^{1}$ I watched the approach of two men along the edge of the gently lapping reef waters. Both men were armed with the multipronged fishing spear found throughout New Guinea, and both were on the look- closely connected with this is the pleasure motive. I could always pick out the fishermen among the natives that visited my house by the obvious signs of pleasure they exhibited when shown my large assortment of hooks and fishing twine. Perhaps, in this connection, it may be interesting to note the attitude of the out for any stray fish that might be lurking among the shallows. On arriving at a point opposite to the beached canoe, one of the men came up to me and, squatting down, began to talk about things in general. He explained that at this time of the year most men had plenty of time on their hands, as the yam harvest was concluded and new gardens would not have to be prepared for at least a month. In consequence, many men took to fishing. On

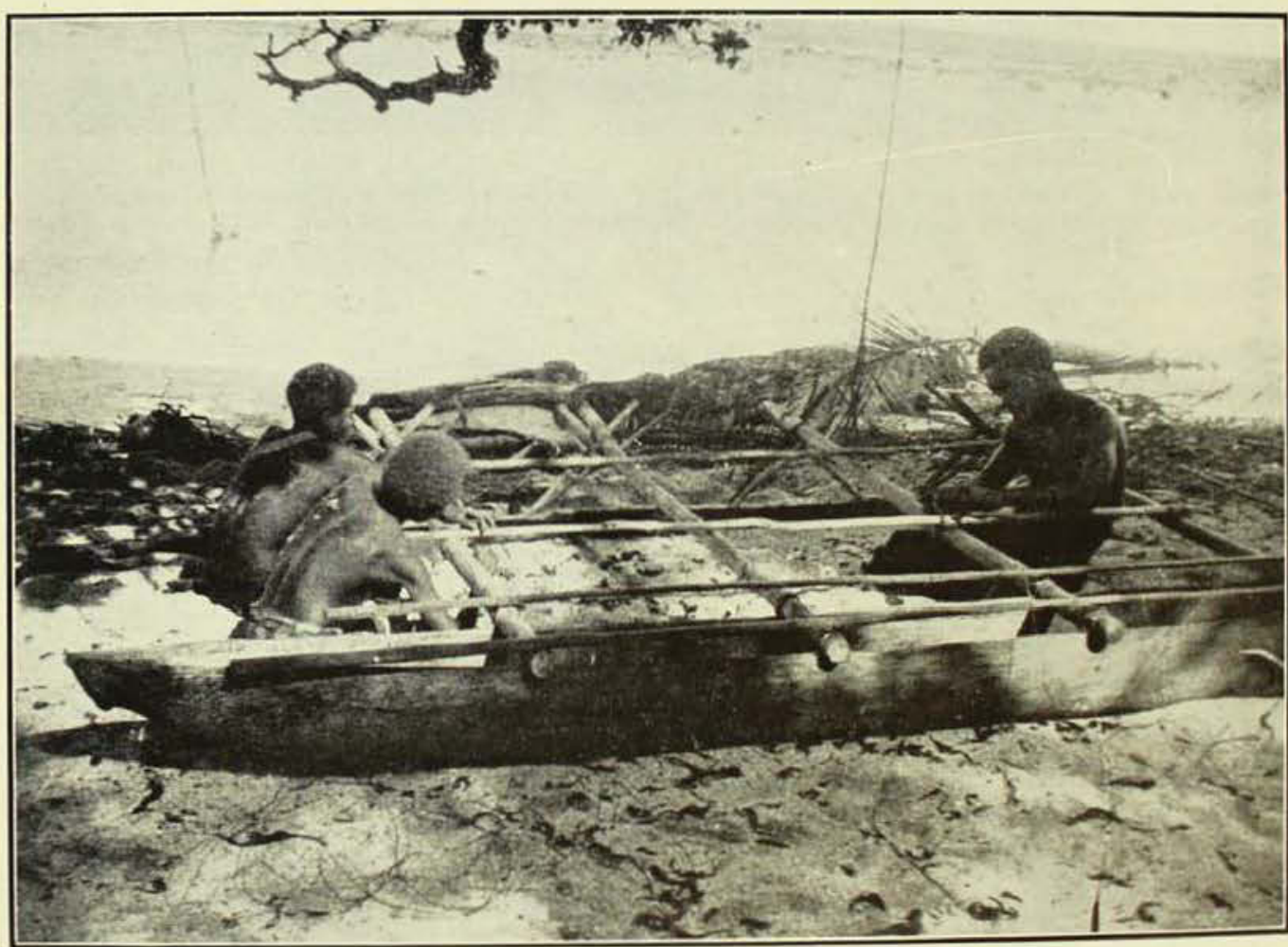

Repairing a small fishing eanoe of the outrigger type (wang). [Photo. - F. L. S. Bell, inquiring why there

were not more of them on the reef, he shrugged his shoulders and said that they were either too lazy to fish or they were not sufficiently skilled in the art. It appears that in Tanga, where there is an abundance of other food, fishing is only pursued by men who enjoy catching fish. The main drive behind the occupation is undoubtedly the securing of food, but

${ }^{1}$ During 1933 the writer earried out anthropological field-work in this area of the Bismarck Archipelago for the Australian National Research Council. native towards the white fisherman. My few fruitless excursions to the reef with rod and line aroused both amusement and amazement-amusement at my poor efforts to land a fish and amazement at my ever attempting to do so, seeing that I had such an abundance of tinned food in my house.

As I chatted with my native friend, I noticed his companion and a small boy gathering shell-fish along the seaward edge of the reef. The boy had charge of 


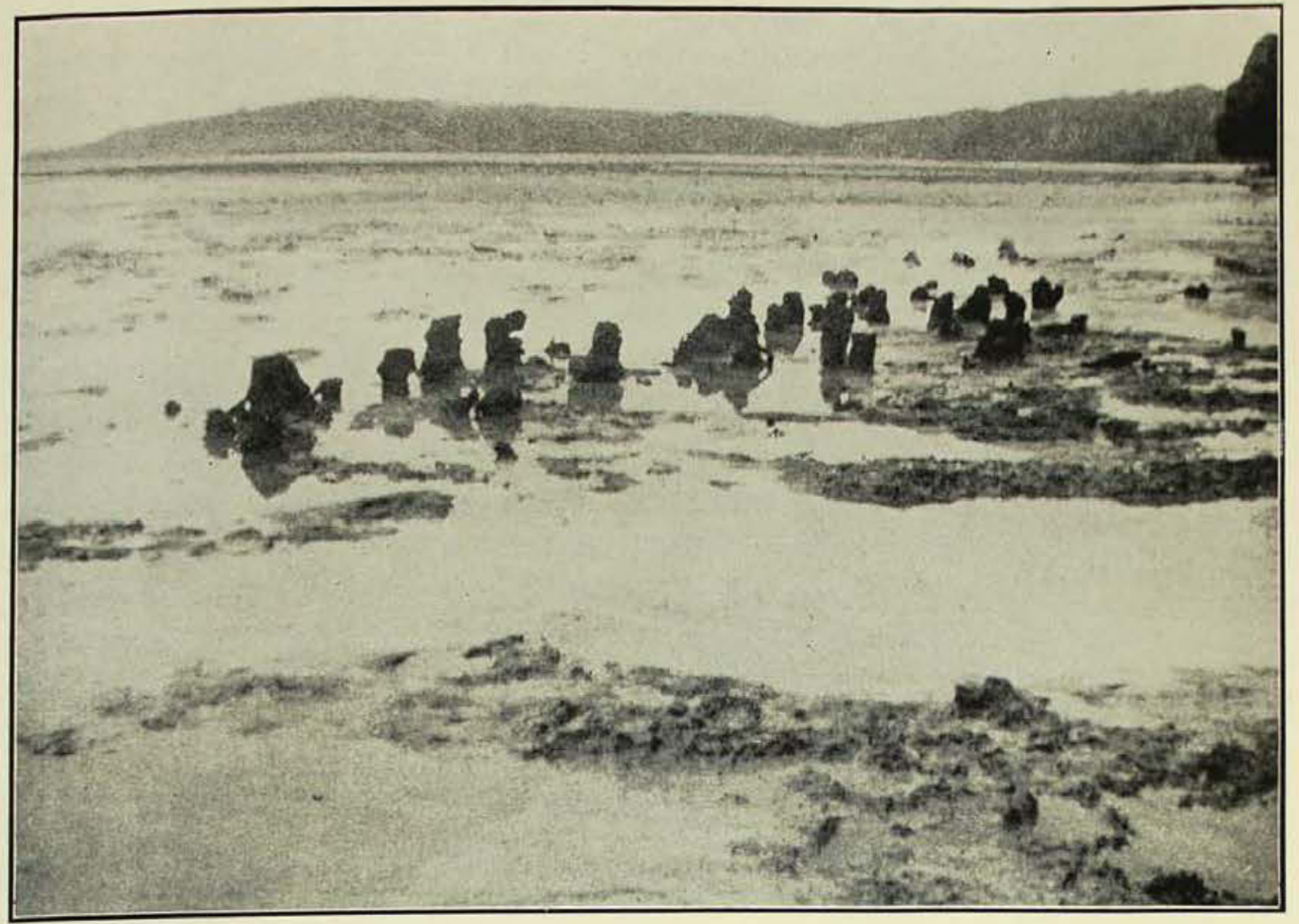

The reef at low tide. The dark coral pillars in the foreground represent women who were turned to stone because they were too late for a feast.

the fishing basket, which he had propped up on a coral boulder out of the way of the surf, and was industriously cracking open the shell-fish for his elder relative. The latter had selected a spot near the channel leading into the reef and, after spitting out some "berley" consisting of partly masticated shell-fish, he baited his tortoise-shell hook and cast out his rod. It was no time before we saw the backlash of the rod and the gleam of a fish on the end of the line. After biting the fish behind the head, he threw it to the boy, who placed it in the fishing basket.

My informant, fired by the success of his companion, decided to try his luck, and, selecting a small rod and an equally short line, he began to fish for bait in a nearby shallow pool. No form of hook was necessary, a small ball of spider-web, about the size of a pea, being the only lure used. After collecting sufficient bait, he joined his companion on the reef, and with the aid of an eight foot bamboo rod and about six feet of line it was not long before he had caught sufficient to supply both himself and some of his closer [Photo.-F. L. S. Bell.

relatives with a good meal of grilled rockcod.

As an alternative to catching bait by means of a spiderweb lure, the nuts of the Barringtonia speciosa are stripped and grated into the reef pools. Certain poisonous barks are also used in this way, so as to either kill or stupefy the fish, which then can be caught easily by hand.

Occasion a 11 y a small scoop-net, operated by one man, is used to catch stray members of a shoal which has entered the reef waters. However, the very rugged nature of the reef militates against the use of nets, and although I saw large seine nets with carved floats

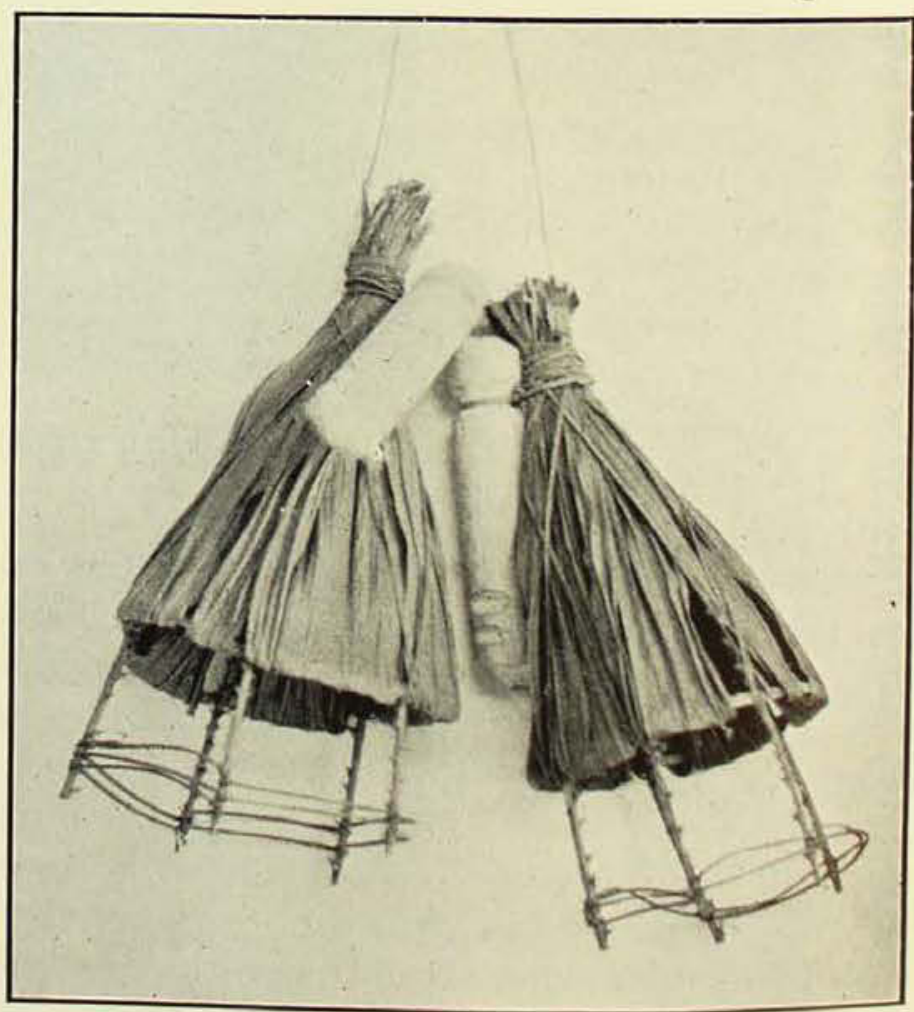

Thorn fish-traps (an kula). Note the ovner's distinguishing mark on the wooden float. [Photo.-F. L. S. Bell. 


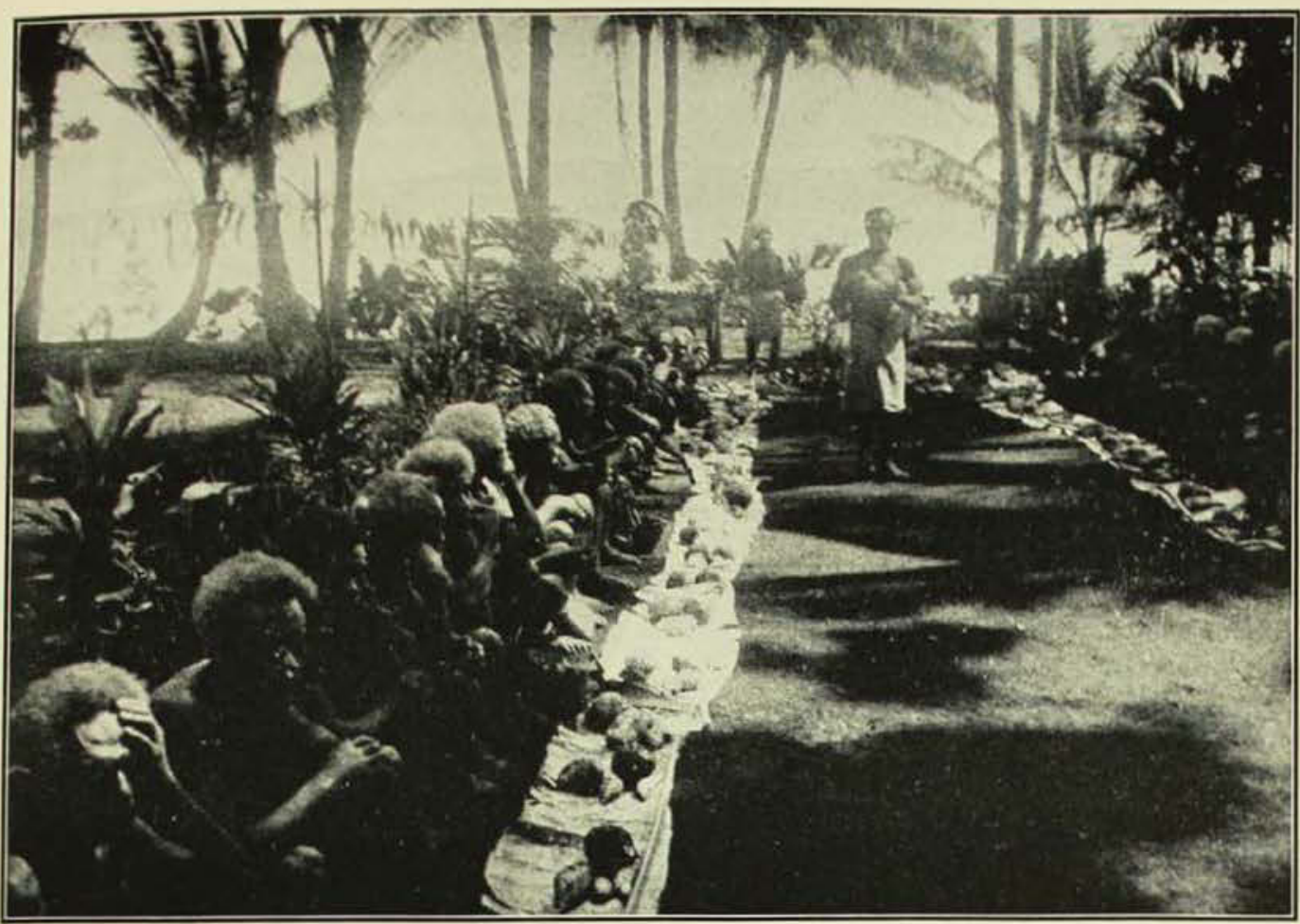

Fish was the pièce de résistance at this feast.

[Photo.-F. L. S. Bell. fish into the shallow beach portion of the reef waters.

So far I have only described the desultory efforts of those natives who are sufficiently interested as individuals in the art of fishing.

Fishing, however, is a well-organized occupation at certain times in Tanga, and it is the ritual aspects of fishing to which I now wish to draw your attention.

On the northern side of the island a coral cliff descends sheer into the deep blue waters of the preserved in some of the houses, I never saw them used during my stay on the island. I doubt very much whether they were ever used on Boieng, and I have information which suggests that they were made only for purposes of hire to other islanders whose waters were more suited to this type of fishing.

Although large nets are rarely, if ever, used to trap a shoal of fish, the natives of Tanga have another method of fishing, the success of which depends a great deal upon their accuracy with the spear. One morning I was astonished to hear cries and shouts, mingled with sharp rifle-like reports, coming from the reef waters. I rushed down to the beach and there, strung out in a long line which was gradually working its way from the entrance of the channel to its shallow end, were twenty-five young men, each one slapping the surface of the water with the stem of a coconut frond and shouting to the top of his voice. In his right hand was poised a fishing spear, with which great slaughter was being done upon the floundering mass of fish. For days after the visit of this shoal of fish the children played at driving an imaginary shoal of
Pacific. During August and September this is a fisherman's paradise, as the spot is a favourite basking place for very large fish. The native names for some of these fish are saelil, tutu, les and kahbel, and it is claimed that they measure up to four feet in length. As this fishing ground is some distance from the inhabited part of the island, those men who join the fishing party camp on the spot during operations. Several of my informants admitted to me that their wives objected to being left alone for so long, and one even confessed that next year he would rather stay at home than endure the ensuing wrath of his wives.

For such large game, a well selected bamboo rod about eighteen feet long is prepared, and to this rod about five fathoms of strong native twine is attached. A large tortoise-shell or wooden hook, around which much spiderweb silk is wound, forms the lure, and falling from the free end of the line is a stronger piece of twine called an matanwa or, literally, "the eye of the line". At the rear of the fishermen, who line the edge of the cliff, is a long low bamboo fence. This fence is erected in order to 
prevent fish which have been hooked from jumping back into the sea. On the man at the head of the line signalling the approach of a school of fish, each native throws out his $1 \mathrm{ure}$ and sweeps it invitingly across the surface of the water. According to accounts, it is no time before fish are being snapped out of the water and deposited, in on e movement, at the rear of the bamboo wall. As lines do

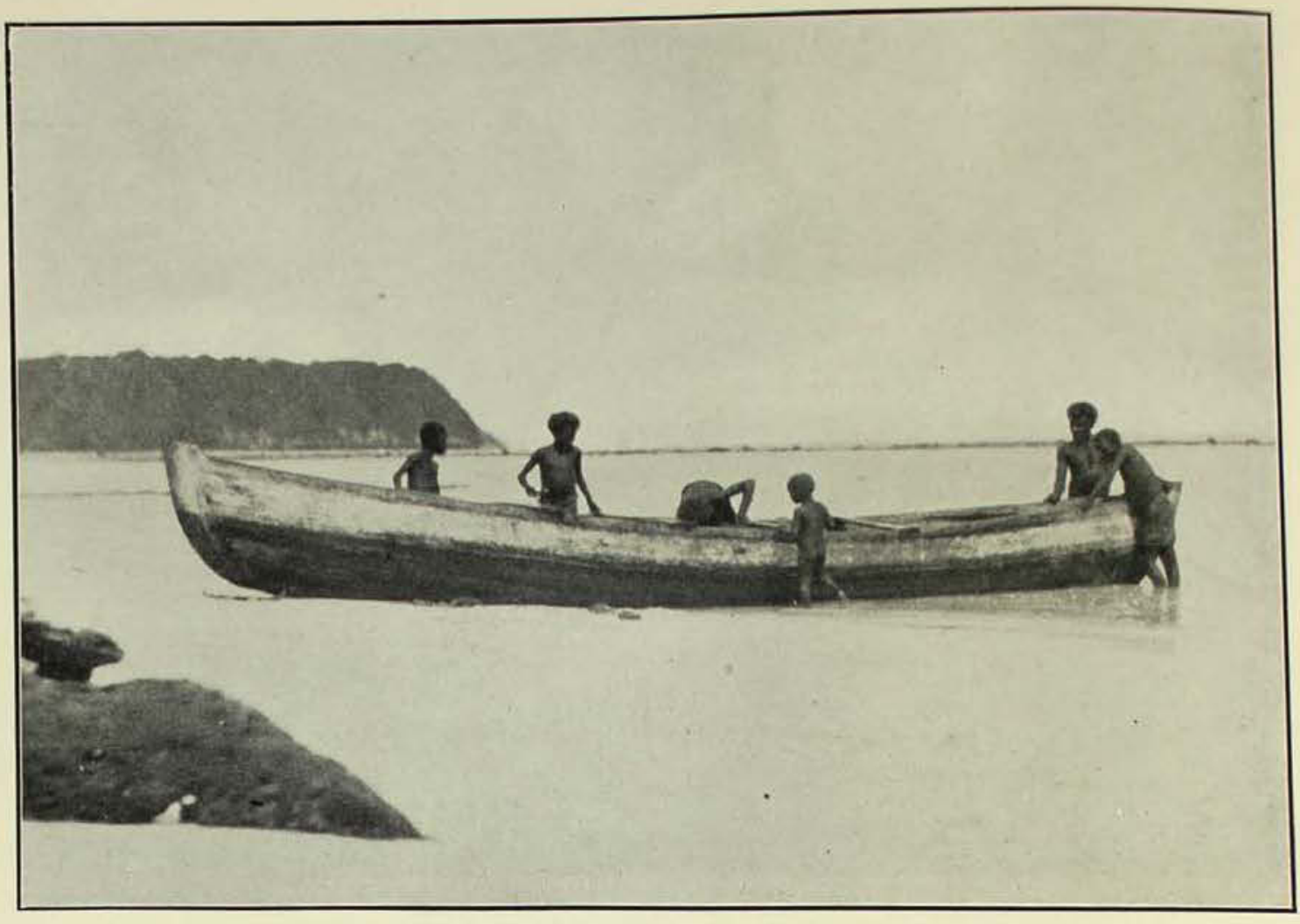

Beaching a large plank canoe (mon).

[Photo,-F. L. S. Bell.

not have to be

baited or hooks removed from the jaws of the fish, it is simply a matter of the man who works fastest making the best catch.

When things are dull and the fish are not biting, the natives believe that the fish are hungry and need feeding. Crayfish, cuttlefish and crab are then caught and cooked. A meal is made off these dainties, and the remains are wrapped into a number of small bundles (fis kot kot). Each fisherman ties one of these bundles to the end of his line by a thin piece of banana fibre. As he fastens it on, he sings this spell into the bundle:

Who is it that catches fish with the talons of a sea-eagle?

I am he that catches fish with the talons of a sea-eagle.

Hey! there are thorns of the cane plant close to the point of my hook,

Hey there, si si si (repeated). ${ }^{1}$

Whatever bait is not used in making fis kot kot is thrown into the water, and when the fish come to the surface to feed upon this berley, the lines are thrown out

${ }^{1} \mathrm{Si}$ (repeated): This is the sound made by a fisherman when he is jerking up a big fish with his rod. and the magic bundles are released. My informants assured me that a good catch always resulted from carrying out this simple act of magic. Of course, huge quantities of fish were caught by such expeditions, but there was never any difficulty in disposing of the catch. The amount of food consumed at a native feast must be seen to be believed.

In preparation for a big funeral feast or the coming of age of the son of an important man, a large part of the fishing grounds was placed under a taboo-it was rendered ta: $m$. Those men of the clan who wished to take part in the ritual fishing operations which marked the end of the period of prohibition, took leave of their wives and children some months beforehand, and placed themselves under the command of a fishing expert (an waran kok). Their first act was the construction of a large dwelling house called ful-an-anuf.

The system of fishing employed by these men on such occasions may be termed the thorn-trap method, and every operation connected with the making of the traps is carried out inside the special 
fishing house or within the prohibited area. The lines connecting the float with the trap, the floats, the thorny ribs which make up the framework and all other accessories are made and obtained on the spot. Every operation is carefully supervised by the fishing expert, including the construction of special bamboo rafts (rau$u t)$.

When the expert decides that it is time to make the traps, he war ns

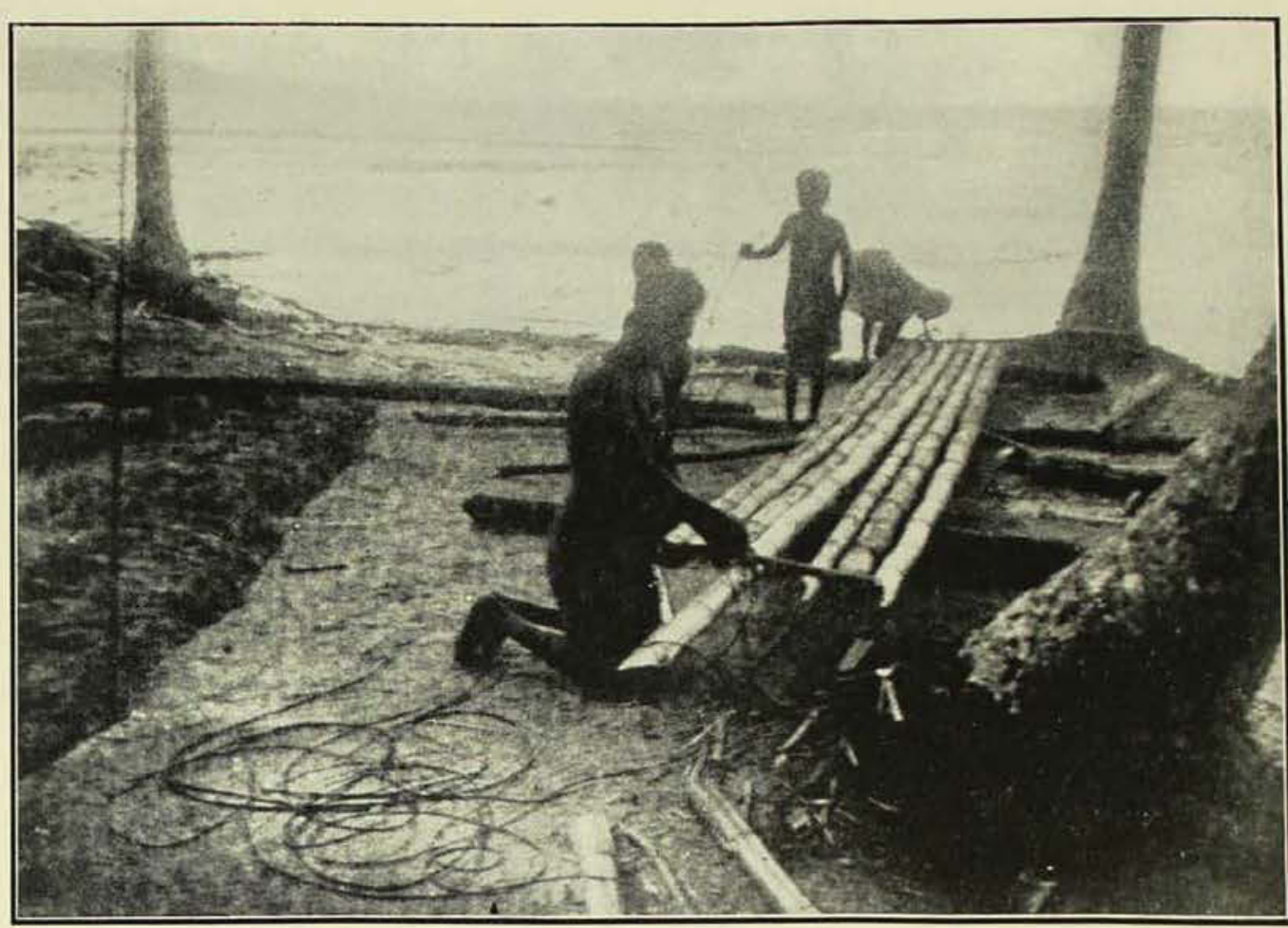

At work on a bamboo fishing raft (ran-ut). [Photo.-F, L. S. Bell. the fishermen to assemble on the beach at daybreak of the following day. In preparation for this, a long bamboo seat is made on the beach facing the water, and every two yards a forked stick is set up and a layer of leaves is set down at its base. The forked stick will hold the finished traps, and the leaves will prevent the coral sand from getting into the fishing twine.

The old expert-he is generally an old man-then repairs to the bush and, selecting a bunch of fele leaves and some watwat fibre, he sings into them a magic spell, calculated to obtain the aid of the ancestors in the morrow's fishing drive

It would be wearisome to recount each step in the making of the fish traps, but there is one aspect of these operations which must be emphasized. Each process is carried out in perfect unison and in perfect silence. I was told that one thoughtless word or action would spoil the whole proceedings.

If any unauthorized person is caught watching the process of manufacture, he is punished by having his hand thrust into the trap and then having the trap pulled off-a procedure calculated to leave very painful lacerations.
When a sufficient number of traps are made, the men are instructed to fish for bait. The expert then orders all to take their rest and in the early morning, at the rising of a star ${ }^{1}$ called an matlien, he rouses them from their beds and orders them to set their traps in the deep water just beyond the reef. The traps are soon set and it is not long before the floats start to pop up with struggling fish attached. Each float bears its owner's particular mark, and no matter who gathers in the float, there is no difficulty in distinguishing the owner of the fish.

By carrying on in this manner for two or three days, a vast quantity of fish is acquired. Of course, it is so necessary that a super-abundance of food should be at hand on festal occasions, since the success of a feast in Melanesia always depends on the size of the menu.

From the above account it is apparent that although fishing has little attraction for the individual native, yet as an organized group activity, reinforced and controlled by magic, it takes its place as an important means of contributing to the food supply of the island. 


\title{
Wonders of the Ant World
}

\author{
By Keith C. McKeown.
}

Part I.

$\mathrm{T}^{1}$ HROUGHOUT the ages man has taken the keenest interest in ants and their ways. The reason for this interest lies undoubtedly in the points of resemblance which exist between the social life of the bees, ants, and wasps and that of ourselves, since man's attention has been attracted generally to the social insects, almost to the exclusion of the others, with the exception of the purely asthetic interest taken in a few other groups.

The social insects, living in highly organized communities, are possessed of extraordinary instincts which compel the notice of even those persons to whom an insect is not worthy of even passing interest. In many cases the resemblances to our own institutions are superficial, but there remain many undoubted parallels. There has been a tendency in recent years to impute human thoughts and motives to the ants, and other highly developed insects, but, on detailed study, we find that the insect lives in a very different world to our own, being tied to a wheel of routine which must be followed automatically, although here and there one may find gleams of indisputable intelligence and initiative. The insect too comes under the sway of influences quite outside its own control-these are known as tropisms; thus there is phototropism, the attraction to artificial light, which causes the moth to fly unerringly into the flame of the candle, quite without its own volition. There is heliotropism or attraction to natural light; chemotropism, the attraction to various chemical substances or emanations, and many more.

Ants are to be found practically throughout the world, with the exception of the Antarctic, and they have penetrated into almost every region by their power of exploiting nearly all available means of life.

The geological history of the ants is an ancient one, fossil ants being found in large numbers in the Tertiary deposits: here they appear so suddenly and in such numbers that it is evident that they must have existed from a very much earlier period, although no fossils have yet been found in older deposits. Everyone is familiar with the term "a fly in amber"; many of the fossil ants have come down to us in this form, having, long ages ago, become embedded in the resin while it was liquid, and on its hardening have been preserved as they died, perfect in every detail. The modern ants differ but little in structure from their earliest known ancestors.

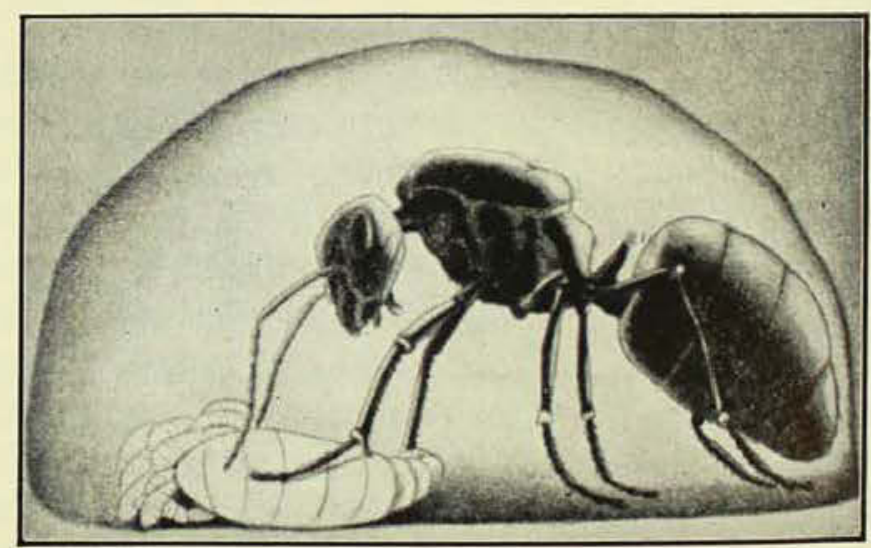

Primary nest formed by Ant (Camponotus lignipera) after nuptial fight showing first bateh of larva cared for by colony founding queen. [After A. Eidmann.

ANT COMMUNITIES.

The ant community may be said to be an organization of females, resembling the mythical communities of Amazons, but, while the Amazons were supposed to be organized for war, the ant colony exists only for the care of the young and the continuance of the race, everything being sacrificed for these ends.

The inhabitants of an ant's nest are winged males and females, the so-called queen, who was, in her youth, winged like her daughters, and the soldiers and workers, both of which castes are sterile females. 
One hot summer day the queen ant of our colony emerged from her home, where she had lived until this day, and together with her sisters and brothers, took flight upon gauzy wings, filling the air with a fluttering swarm of ants from her own and surrounding nests, for a number of nests of the same species in the vicinity usually send forth their swarms on the same day. These flights are known as nuptial flights, and it is here that the ants select their mates. After pairing the female ant falls to the ground, usually at a considerable distance from her old home, and, seeking out a suitable crevice under some stone or piece of bark, divests herself of her wings, biting them off at the base, since they are now useless and only an encumbrance in her new life. Before she left her old home the queen ant was well fed and had stored up large reserves of fat in her body against the time when she must found a new colony. Until the worker ants, which will emerge from the eggs which she now lays, carry on the duties of the nest, the queen does not feed, but lives upon the stores of fat in her body. She lays a few eggs at first, gathering them into a little packet, and stands guard over them until they hatch. The grubs are fed upon saliva, which contains many of the constituents of the fat stores in her body and the now useless muscles of the bases of her wings, which are broken down and assimilated. The ants developing from these grubs or larvæ are usually undersized. As soon as their bodies have hardened, these ants, workers and soldiers, carry out all the work of the nest, and from this time onwards the queen is relieved of all duties except that of egg laying. She now lays hundreds of eggs each day, becoming purely an egg-laying machine, and, since a queen ant may live for twelve or fifteen years, the number produced during her life time is enormous. The so-called queen does not rule the community, in spite of popular opinion on that question, but is just as much a servant of what, in the case of the bees, has been called the "Spirit of the Hive", as any member of the other castes.
The soldiers and workers are all sterile females. The soldiers are equipped with large and formidable jaws, of a nightmare variety of forms, and powerful stings, and upon them devolves the defence of the nest and the carrying out of forays, like the robber barons of old, upon the colonies of other species. In the workers the jaws are usually more adapted to the needs of service, and are suited to the various duties which are carried out by their possessors. Like the soldiers they also are armed with stings for defence, if not for offence. I have mentioned the ants as being equipped with stings, as though this were the rule, but many species do not carry them; their method of attack is to spray their enemies with the poison or squirt it into the wounds made by their jaws or mandibles.

Miss Cheesman has described the curious habits of a small yellow ant, found in the Society Islands. While eating her lunch she placed a piece of sardine on the rock beside her. She says: "In a few minutes it was found by a bigheaded worker of a very common species of ant, who cut off a tasty bit and went away with it. I imagined that there would be no interesting visitors that day because directly this worker reached home a trail of workers would follow her from the nest to see where she got the sardine, and they would speedily clear it away.

"So I did not pay any more attention to the matter until about to collect my belongings to move away; when, glancing at the piece of sardine, to my surprise I saw it was still there. There was no trail of workers and it was apparently untouched. This was most unusual; but on looking closer I saw that numbers of very tiny yellow ants were forming a ring round it, and through my pocketlens their manœuvres were quite clear. Each ant was standing motionless with its body raised at an angle, and appeared to be squirting fluid at any ant which had not the privilege of belonging to its own community. Ants small and large were trying in vain to break through the circle, but they were always routed. 
Meanwhile their own little yellow workers were passing between their comrades and carrying away small portions until the whole had been removed; then the circle broke up in a very orderly manner and the ants dispersed." The poison of ants is formic acid, with possibly the addition of other fluids from accessory glands.

Among both workers and soldiers of some species there is great diversity of form and size. There are large forms, and small forms, workers and soldiers major and minor, ants with small heads, ants with enormous heads, and ants with medium-sized heads.

The duties of defence fall to the lot of the soldiers; the duties of the workers are manifold, the excavation and maintenance of the nest, the care and feeding of the young, the provision of food for all the other members of the community, the care of their live stock and guests, and, in fact, the multitudinous tasks of a thriving colony.

The males usually exist in the nests for a short time only, and are then more or less tolerated for the perpetuation of the race.

Every member of the ant community passes through four stages in its lifehistory, egg, grub or larva, pupa or chrysalis, and the adult insect. The socalled White Ants or Termites are not related to the true ants (Hymenoptera), but belong to another order, the Isoptera. Instead of passing through clearly defined stages the Termites grow by moulding their skins, and the young are simply miniatures of the adult insects. Worker and soldier termites are males and females irrespective of caste.

\section{ANT NESTS.}

Ants' nests are usually simple tunnels in the ground with irregular earthen galleries and chambers branching off the main shaft, but in spite of their general irregularity, there is yet a certain individuality in the work of each species, resulting in the nests of any species all possessing typical features, so that, in many cases the family may be closely determined by the form of the nest without seeing any of the inhabitants. The soil removed from the nest in course of excavation is usually built up into a mound around the entrance. The typical ant nest is that most readily recalled to mind, the so-called crater nest in which the soil is built up into a crater-shaped ring around the entrance. The Bull-dog Ants (Myrmecia) erect over the nest a shapeless mound provided with one or more entrances. The nest of the Jumper Ant (Myrmecia nigro-cincta) is similar in shape to the home of their larger cousins, and usually has a number of exits placed near the base of the mound, from which the fierce insects can sally forth to attack the unsuspecting intruder, who seldom realizes until too late that there are other openings to the mound besides that con spicuously displayed at the summit. The large Meat Ant (Iridomyrmex detectus) constructs large mounds covering quite an extensive area, with the surface covered with coarse gravel, or sometimes with white quartz pebbles. These ants make beaten tracks and pathways through the grass, which is first cut off at ground level, and the constant traffic along these roads soon compacts the soil and prevents the growth of vegetation upon them. The habit of covering the surface of the nest with pebbles and similar objects is a curious one, which is not yet fully understood, but it is believed to provide insulation against the sun's rays. Several species of ants cover the surface of the nest with pebbles, charcoal, the seed-vessels of Eucalypts, and similar objects. Some of the European ants (Formica rufa and others) cover their nests with pine needles, forming enormous mounds up to over six feet in height.

Beneath the ground the nest is found to consist of a number of irregular galleries and chambers excavated in the soil at various depths. Here the eggs and helpless young may be safe from their enemies and yet sufficiently near the surface to benefit from the warmth of the sun. Other galleries are used for the storage of food, dwellings for the adult ants, and similar purposes. Ant nests have been recorded as extending to a 


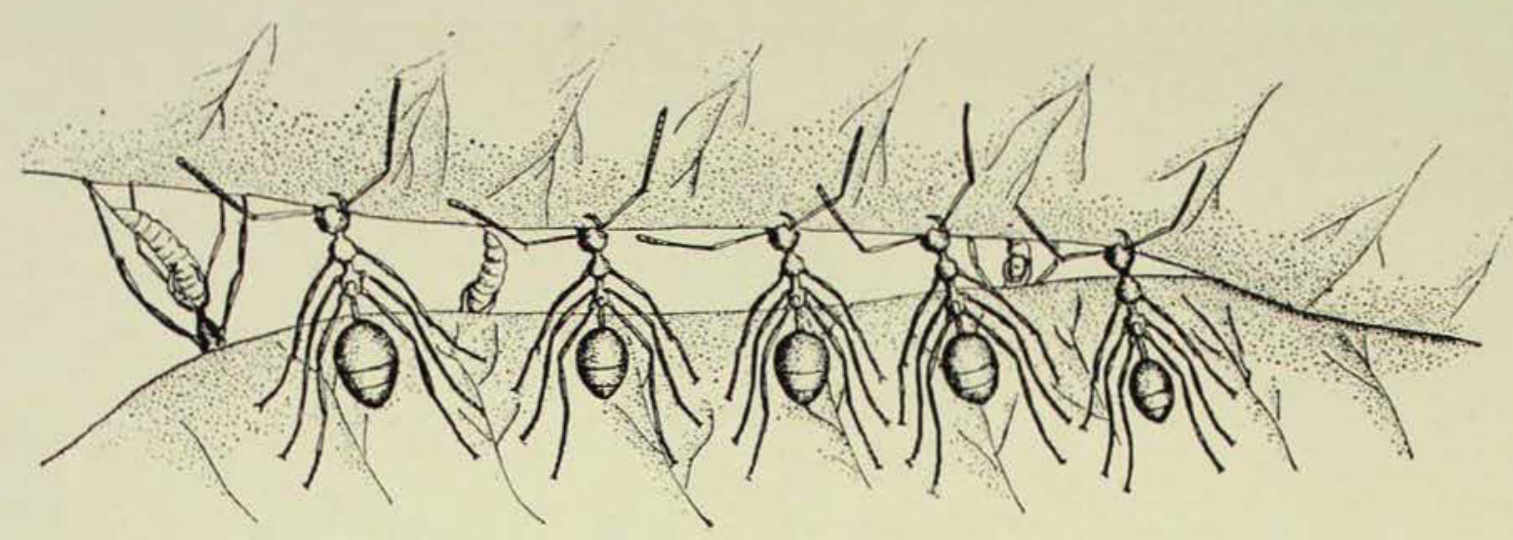

Green Tree Ant (Geophylla smaragdina var. virescens) workers drawing edges of leaves together while other workers vecure them with the silk spun by the larvae.

[After Doflein.

depth of eight or nine feet below the surface, a stupendous feat when one considers the size of the engineer. Most nests, however, seldom extend for more than a few inches to feet below ground level.

\section{GREEN TREE AN'T.}

Some ants, perhaps from force of circumstances over long ages, have abandoned the soil as a site for their homes, and have betaken themselves to life in the trees. Perhaps the most striking example of these tree-dwellers is the Green Tree Ant (Ecophylla smaragdina var. virescens), which ranges from Eastern Asia, through New Guinea, to Northern Australia. This ant constructs silken nests as large as a man's head among the branches of trees. The ants themselves are incapable of producing silk, so they exploit their larva to produce that necessary for the nest-building, and use them as living shuttles. How did the ants discover that they could make use of the silk glands of the larvie for this purpose? We are unable even to suggest an answer. The larva produce the silk for the purpose of covering themselves with silken cocoons when they pupate, or change into the chrysalis state, but by the time the ants have finished using them for nest-construction their silk is exhausted, and they are in consequence forced to sleep naked.

The leaves are drawn together by the united efforts of the workers. Where the foliage is stiff scores or even hundreds of ants may be required to draw a leaf into position. When the leaves are far apart they form long chains, each ant in the chain holding the waist of the one before it with its jaws, and hauling vigorously. The strain on the first ant must, at times, be terrific. Once the leaf has been hauled into the required position it is held in place by the ants, while other members of the colony emerge carrying larva which they use as living shuttles, weaving them backwards and forwards until the leaf is secured with a stout sheet of silken threads.

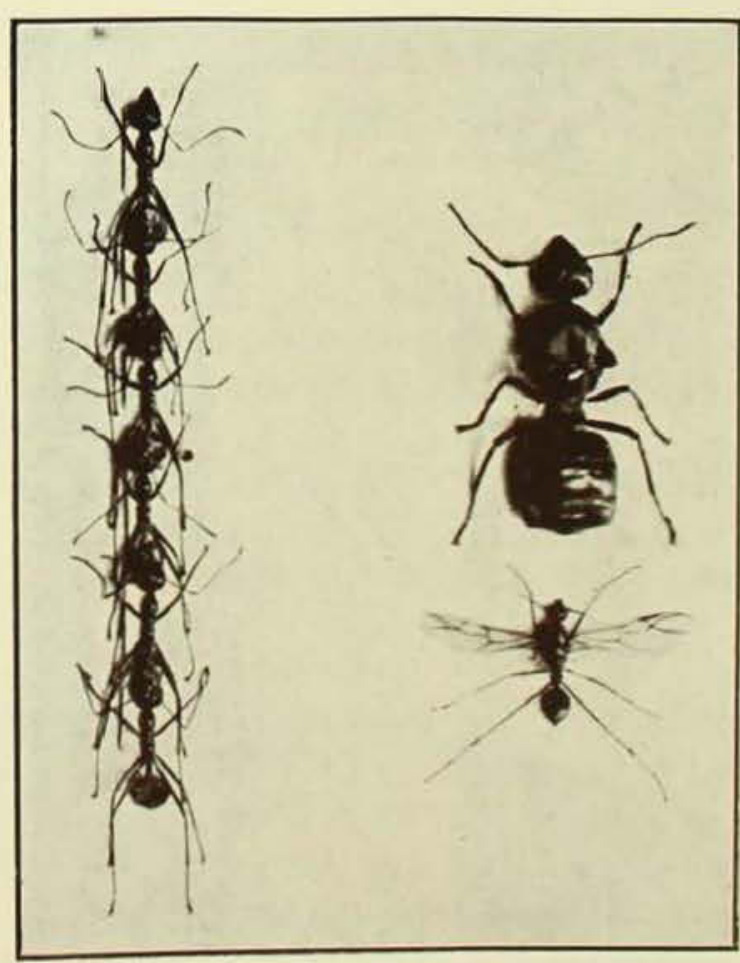

Chain of worker Green Tree Ants formed in draving widely separated leaves together (left), Dealate female or queen (above), and winged male below (lower right).

[Photo.-G. C. Chutton. 


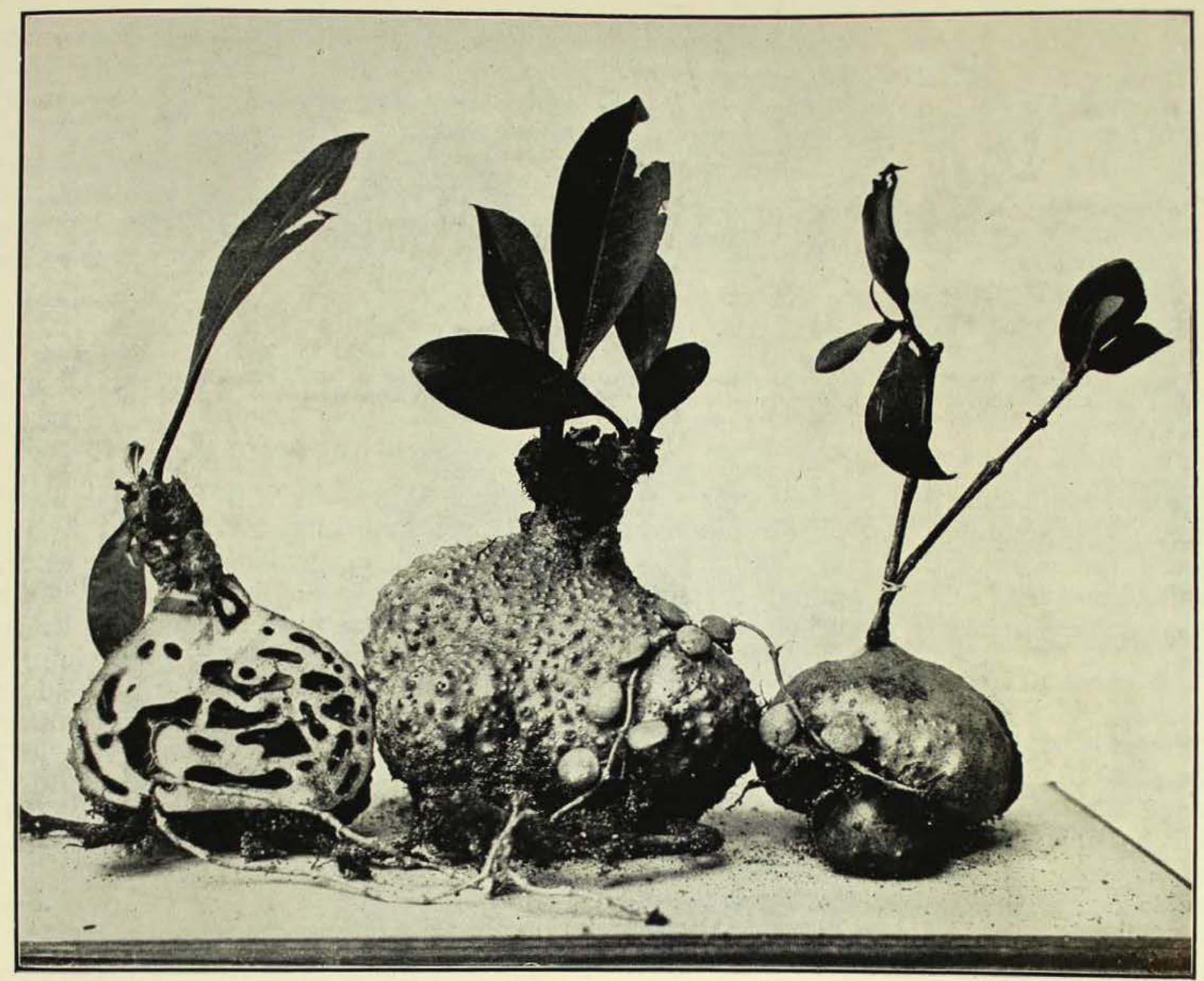

Ant Plants (Myrmecodia) from northern Australia. The plant on the left has been sectioned to show the eavities in the bulb which form their nests.

[Photo.-G. C. Clutton.

Some ants make use of natural cavities in trees and plants in which to make their nests. As a development of this habit, others again cut holes near the tips of the large thorns of an African Acacia, and, cleaning out the pith, use these as homes. There is a mutual benefit in this scheme, for the ants provide a standing army, which swarms out in defence should the shrub be interfered with by grazing animals. In return the plant not only supplies the ants with homes but also provides them with food, for near the base of each leaf are two glands which secrete a sweet honey-like fluid, and at the tip of the leaf is a fleshy knob-like body known as Belt's body, after its discoverer. These food-bodies are greatly relished by the ants, which collect them and store them in their nests, where they are greedily eaten.
Another group of plants, the Myrmecodias, of which we have species in Northern Australia, which are known as "Ant plants", also provide shelter for the ants. These plants, living in dry places, have developed large, bulbous, fleshy stems for the storage of water. These bulbs are filled with cavities which the ants use as nests, piercing the outer wall of the plant to gain access to them. In this case the ants neither benefit nor injure the plant.

In this place mention may be made of the so-called "ant gardens" found in the Amazon valley. These "gardens" consist of large masses of soil carried up by the ants into the forks of branches of trees, and held together by the roots of plants which grow upon this foundation, and in which the ants make their nests. 